\title{
Synthesis and structure of mixed carboxylate-aminopyridinate and -amidinate complexes of dimolybdenum and ditungsten
}

Irene Mendoza, Natalia Curado, Mario Carrasco, Eleuterio Álvarez, Riccardo Peloso, Amor Rodríguez, and Ernesto Carmona*

Instituto de Investigaciones Químicas-Departamento de Química Inorgánica. Universidad de Sevilla-Consejo Superior de Investigaciones Científicas. Avenida Américo Vespucio 49, 41092 Sevilla, Spain.

Keywords: molybdenum; tungsten; carboxylate; aminopyridinate; amidinate; quadruple bond

\begin{abstract}
We describe in this paper the synthesis and structural characterization of dimolybdenum and ditungsten complexes with $\mathrm{M} \equiv \mathrm{\equiv}$ bonds derived from the metal-metal bonded tetracarboxylates $\left[\mathrm{M}_{2}\left(\mathrm{O}_{2} \mathrm{CR}\right)_{4}\right]$ and incorporating one or two bulky aminopyridinate or amidinate ligands. The new compounds were isolated in good yields from reactions of the $\left[\mathrm{Mo}_{2}\left(\mathrm{O}_{2} \mathrm{CR}\right)_{4}\right]\left(\mathrm{R}=\mathrm{CF}_{3}, \mathrm{Me}\right)$ and $\left[\mathrm{W}_{2}\left(\mathrm{O}_{2} \mathrm{CCF}_{3}\right)_{4}\right]$ metal precursors with the lithium salts of several aminopyridinate and amidinate ligands. They have formulations $\left[\mathrm{M}_{2}(\overparen{\mathrm{N} \mathrm{N}})\left(\mathrm{O}_{2} \mathrm{CR}\right)_{3}\right]$ or $\left[\mathrm{M}_{2}(\overparen{\mathrm{N} \mathrm{N}})_{2}\left(\mathrm{O}_{2} \mathrm{CR}\right)_{2}\right](\overparen{\mathrm{N} \mathrm{N}}=$ bridging aminopyridinate or amidinate ligand $)$ and were identified by microanalysis and common spectroscopic techniques. Nine of the newly reported complexes were additionally characterized by X-ray crystallography.
\end{abstract}

\section{Introduction}

The dimetal tetracarboxylate complexes of molybdenum and tungsten, $\left[\mathrm{M}_{2}\left(\mathrm{O}_{2} \mathrm{CR}\right)_{4}\right]$, constitute a wellknown family of metal-metal bonded complexes. Because of their versatility, the dimolybdenum derivatives, originally prepared by Wilkinson and co-workers some fifty years ago [1], are considered as the most important class of compounds to contain a Mo-Mo quadruple bond [2]. At variance with their facile synthesis, the isolation and structural characterization of the tungsten analogues was not straightforward. However, after several unsuccessful attempts, the trifluoroacetate $\left[\mathrm{W}_{2}\left(\mathrm{O}_{2} \mathrm{CCF}_{3}\right)_{4}\right]$ was finally reported by Sattelberger et al. in 1981 [3].

Compounds of this kind exhibit a paddle-wheel structure. Since the carboxylate groups participate in facile ligand substitution reactions, a large number of compounds where one or more carboxylate groups have been replaced by different non-labile bidentate ligands that are also capable to bridge the multiply bonded metal atoms, are presently known [2]. Different researchers have exploited this methodology which permits subsequent substitution of the more labile carboxylate groups, to generate quadruply bonded $\mathrm{Mo}_{2}{ }_{2}$ and $\mathrm{W}_{2}^{\mathrm{II}}$ complexes with unusual, interesting geometrical and electronic structures [4-6].

\footnotetext{
* Corresponding author. Tel.: fax: (+) 34-954460565.

E-mail address: guzman@us.es (E. Carmona).
} 
In the last two decades the use of very bulky ligands has become an important, widely used strategy in synthetic organometallic chemistry and catalysis [7]. This is doubtless due to the kinetic stabilization that these ligands confer to the reactive low coordination number complexes and intermediates that they may form. In the field of metal-metal bonding, bulky terphenyl [8], aminopyridinate [9], amidinate [10], diazadiene [11], guanidinate [12], and other ligands [13-16], have attracted considerable attention in recent years (Fig. 1). Potentially, these non-labile ligands can replace one or more carboxylate groups in the quadruply bonded $\left[\mathrm{Mo}_{2}\left(\mathrm{O}_{2} \mathrm{CR}\right)_{4}\right]$ molecules maintaining their characteristic paddle-wheel-type structure. Indeed, many bis(carboxylate) bis(amidinate) complexes (Fig. 1, structure c) have been known for many years [2]. Recently, bis(carboxylate) bis(terphenyl) dimolybdenum complexes have been reported too [17]. Obviously, terphenyls are monodentate ligands, but the flanking aryl ring that positions itself over the other metal atom (structure $\mathbf{a}$ in Fig. 1) can either participate in a weak $\mathrm{M}-\mathrm{C}_{\text {arene }}$ bonding interaction [8,17] (socalled secondary interaction [8]) or play a protective role and act as steric guard.

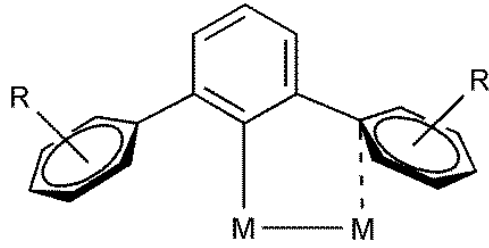

a

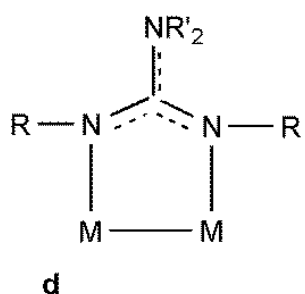

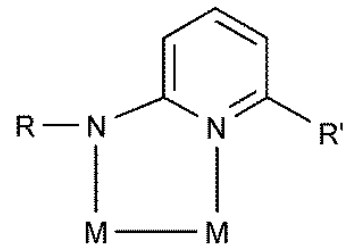

b

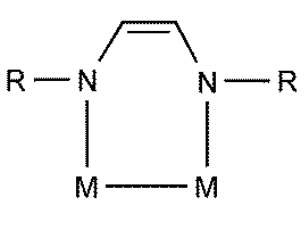

e
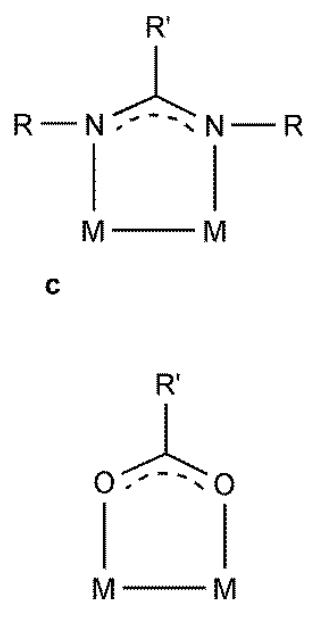

$\mathbf{f}$

Fig. 1. Some bulky ligands commonly employed to stabilize multiple $\mathrm{M}-\mathrm{M}$ bonds that may formally replace bridging carboxylate groups.

We have recently utilized some $\left.\left[\mathrm{Mo}_{2}\left(\mathrm{O}_{2} \mathrm{CR}\right)_{2} \text { (amidinate }\right)_{2}\right]$ complexes that feature a $\mathrm{Mo} \equiv \mathrm{\equiv o}$ bond for the synthesis of low-coordinate, electronically unsaturated $\mathrm{Mo}_{2}^{\mathrm{II}}$ and $\mathrm{Mo}_{2}{ }_{2}$ complexes, the latter containing a molecule of benzene or other arene bound to the Mo-Mo quintuple bond [18]. With the aim of broadening the synthetic scope of such quadruply bonded dimetal precursors, we have prepared a series of complexes of composition $\left[\mathrm{M}_{2}(\overparen{\mathrm{N} \mathrm{N}})_{2}\left(\mathrm{O}_{2} \mathrm{CR}\right)_{2}\right]$ containing aminopyridinate and amidinate ligands (structures $\mathbf{b}$ and $\mathbf{c}$, respectively, in Fig. 1). In this contribution we focus on the reactivity of the carboxylates $\left[\mathrm{M}_{2}\left(\mathrm{O}_{2} \mathrm{CR}\right)_{4}\right](\mathrm{M}=$ Mo, $\mathrm{R}=\mathrm{Me}, \mathrm{CF}_{3} ; \mathrm{M}=\mathrm{W}, \mathrm{R}=\mathrm{CF}_{3}$ ) towards the lithium salts of various aminopyridinate and amidinate 
groups (Fig. 2) to yield corresponding $\left[\mathrm{M}_{2}(\widehat{\mathrm{N} \mathrm{N}})_{2}\left(\mathrm{O}_{2} \mathrm{CR}\right)_{2}\right]$ molecules. Some tris(carboxylate) aminopyridinate or amidinate complexes are also reported.
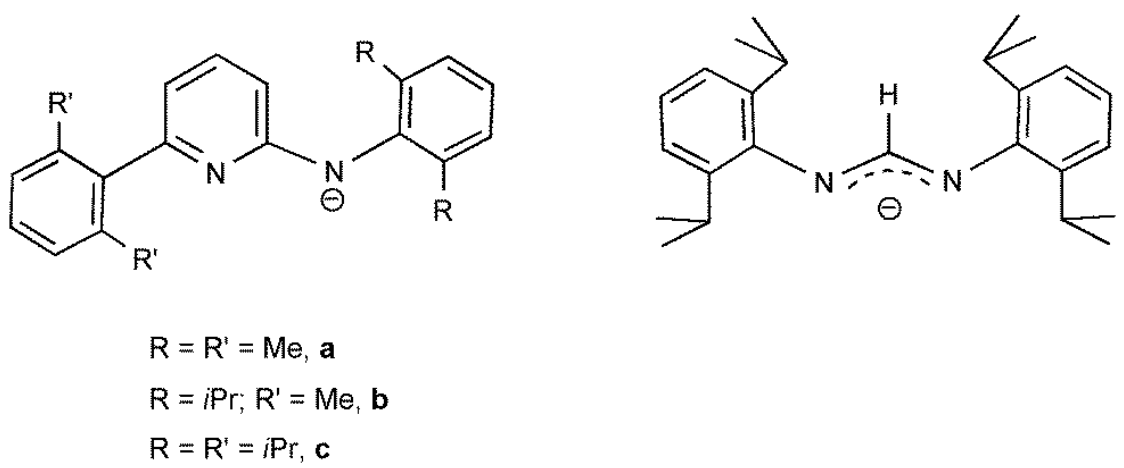

Fig. 2. Aminopyridinate (left) and amidinate (right) ligands employed in this work. In the numbering scheme used throughout this paper aminopyridinate complexes bear labels $\mathbf{a}, \mathbf{b}, \mathbf{c}$ as defined above.

\section{Results and discussion}

\subsection{Complexes with aminopyridinate ligands}

Aminopyridinate ligands were first reported in 1984 by Clegg, Snaith, and co-workers [19] and were subsequently modified by the group of Kempe [20] to provide enhanced steric protection to metal centres. These researchers [20] and others [21] have made ample use of these bidentate monoanionic ligands in the chemistry of electropositive metals, mostly Group 3 metals including some lanthanides. Lately, Kempe et al. have exploited the steric protection that they provide to stabilize the $\mathrm{Cr}-\mathrm{Cr}$ quintuple bond [9].

We found that lithium aminopyridinate reagents, LiAp' (Ap' is used as shorthand notation for aminopyridinates) were able to replace one or two trifluoroacetate groups in $\left[\mathrm{Mo}_{2}\left(\mathrm{O}_{2} \mathrm{CCF}_{3}\right)_{4}\right]$ to yield corresponding mono- and bis-aminopyridinate complexes $\left[\mathrm{Mo}_{2}(\mu-\mathrm{Ap})\left(\mu-\mathrm{O}_{2} \mathrm{CCF}_{3}\right)_{3}\right], \mathbf{1}$, and $\left[\mathrm{Mo}_{2}(\mu-\right.$ $\left.\left.\mathrm{Ap}^{\prime}\right)_{2}\left(\mu-\mathrm{O}_{2} \mathrm{CCF}_{3}\right)_{2}\right], 2$, respectively. Thus, mixing the two reactants in a 1:1 molar ratio (Scheme 1) gave compounds 1b and 1c (see Fig. 2 for the labelling scheme employed in this paper), whereas utilization of a slight excess of LiAp' (ca. 2.1 equiv) provided their $\mathbf{2 b}$ and 2c counterparts, in all cases in good isolated yields (ca. 55-60\%). As represented also in Scheme 1, complexes 1 reacted with a second equivalent of the appropriate LiAp' salt to furnish complexes 2.

The newly formed compounds $\mathbf{1}$ and $\mathbf{2}$ are yellow or orange crystalline solids, fairly soluble in common organic solvents, including saturated hydrocarbons. They are appreciably reactive toward oxygen and water and must be manipulated and stored under an inert atmosphere $\left(\mathrm{N}_{2}\right.$ or Ar). The presence of bridging trifluoroacetate groups is indicated by the observation of characteristic IR bands [22] in the region 1615$1440 \mathrm{~cm}^{-1}$ (see experimental section 3.2) due to $v_{\mathrm{as}}$ and $v_{\mathrm{s}}$ of the carboxylate groups, as well as others in the proximity of $1200 \mathrm{~cm}^{-1}$ attributed to $v(\mathrm{C}-\mathrm{F})$. 
In the ${ }^{19} \mathrm{~F}$ NMR spectrum, complexes 1 exhibit two resonances with chemical shifts -72.6 and $-72.9 \mathrm{ppm}$ (data for $\mathbf{1 b}$ ) and intensity ratio 2:1, in accordance with the formulation proposed in Scheme 1. The ${ }^{1} \mathrm{H}$ NMR spectra of the compounds display the signals expected for the coordinated Ap' ligand. For example, in the spectrum of 1c where the substituents of the two aryl rings are iso-propyl groups, there are two $\mathrm{CHMe}_{2}$ septets (2.51 and $2.77 \mathrm{ppm}$ ) as well as four doublets (between 0.86 and $1.40 \mathrm{ppm}$ ) attributable to the eight methyl groups. The ${ }^{1} \mathrm{H}$ NMR spectrum of $\mathbf{1 b}$ hints that there is a molecule of $\mathrm{Et}_{2} \mathrm{O}$ of solvation, later confirmed by X-ray studies (vide infra).

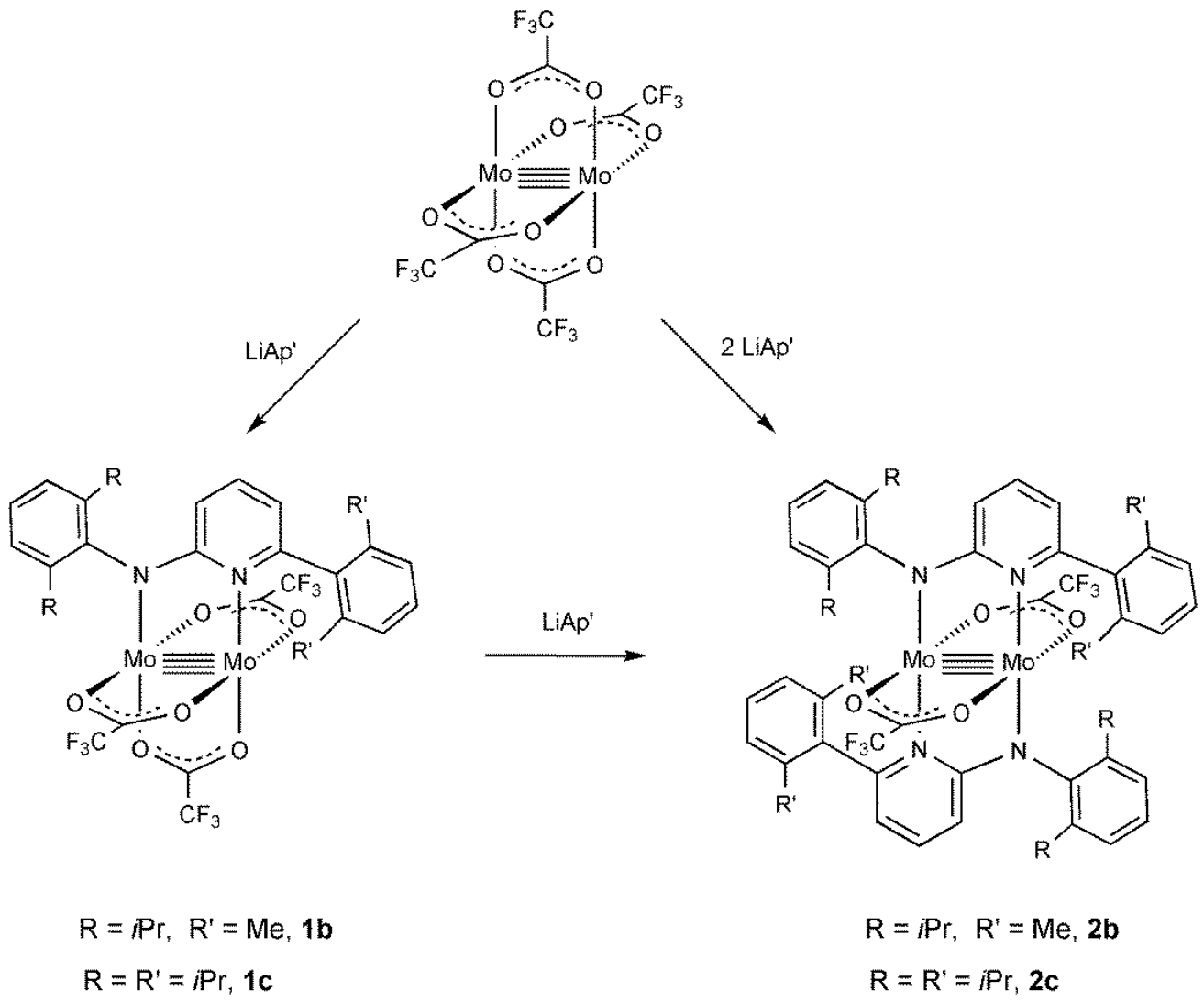

Scheme 1. Synthesis of mono- and bis-aminopyridinate complexes 1 and 2, respectively.

Interestingly, whereas the ${ }^{19} \mathrm{~F}$ NMR spectrum of the bis(trifluoroacetate) compound $\mathbf{2 b}$ contains the foreseen resonance $(-71.7 \mathrm{ppm})$, that of $2 \mathrm{c}$ features two signals with $\delta-70.9$ and $-72.6 \mathrm{ppm}$ and a relative intensity that varies somewhat from one preparation to another. This unanticipated complexity is also evident in the ${ }^{1} \mathrm{H}$ and ${ }^{13} \mathrm{C}\left\{{ }^{1} \mathrm{H}\right\}$ NMR spectra recorded for this complex. For instance, the ${ }^{1} \mathrm{H}$ NMR spectrum contains four $\mathrm{CHMe}_{2}$ septets (between 3.19 and $2.65 \mathrm{ppm}$ ) along with eight $\mathrm{CHMe}$ doublets (in the range 1.29-0.93 ppm). These data suggest the presence of two isomers. A cis, cis arrangement of the two Ap' ligands appears unlikely in view of the steric requirements of the two 2,6-i- $\operatorname{Pr}_{2}-\mathrm{C}_{6} \mathrm{H}_{3}$ substituents. Accordingly, it is possible that the stereoisomer represented in Scheme 1 be accompanied by another trans, trans isomer in which the two $\mathrm{N}_{\text {amido }}$ and the two $\mathrm{N}_{\mathrm{py}}$ donor atoms occupy opposite coordination positions. Indeed the crystals of $\mathbf{2 c}$ chosen for the X-ray studies discussed next unequivocally demonstrate the trans- 
$\mathrm{N}_{\mathrm{amido}}$ and trans- $\mathrm{N}_{\mathrm{py}}$ arrangement of the aminopyridinate ligands. We have not pursued the isolation of crystals of the other stereoisomer.

Complexes 1 and 2 have been studied by X-ray crystallography and their molecular structures are represented in Figures 3 and 4. They all exhibit a paddle-wheel structure and a Mo-Mo bond of length $c a$. $2.10 \AA$, which is nearly identical to that found in the parent $\left[\mathrm{Mo}_{2}\left(\mathrm{O}_{2} \mathrm{CCF}_{3}\right)_{4}\right](2.09 \AA)$ [22]. In the monopyridinates 1b and 1c (Fig. 3), the Mo- $\mathrm{N}_{\text {amido }}$ distance of $2.09 \AA$ is slightly shorter than the Mo- $\mathrm{N}_{\mathrm{py}}$ separation of $2.12 \AA$ and for the $\mathrm{CF}_{3} \mathrm{CO}_{2}{ }^{-}$group in trans with respect to the Ap' ligand the Mo-O distance trans to $\mathrm{N}_{\text {amido }}$ is somewhat longer than the other trans to $\mathrm{N}_{\mathrm{py}}(2.17$ and $2.13 \AA)$ reflecting the higher trans influence of the $\mathrm{N}_{\mathrm{amido}}$-donor atoms relative to $\mathrm{N}_{\mathrm{py}}$. The solid state structure of complex $\mathbf{1 b}$ contains a weakly bonded diethyl ether molecule at distance of 2.528(2) Å. For comparison, in quadruply bonded dimolybdenum complexes stabilized by terphenyl ligands, the Mo-O distance for the coordinated diethyl ether is ca. $2.25 \AA[17 \mathrm{c}]$.
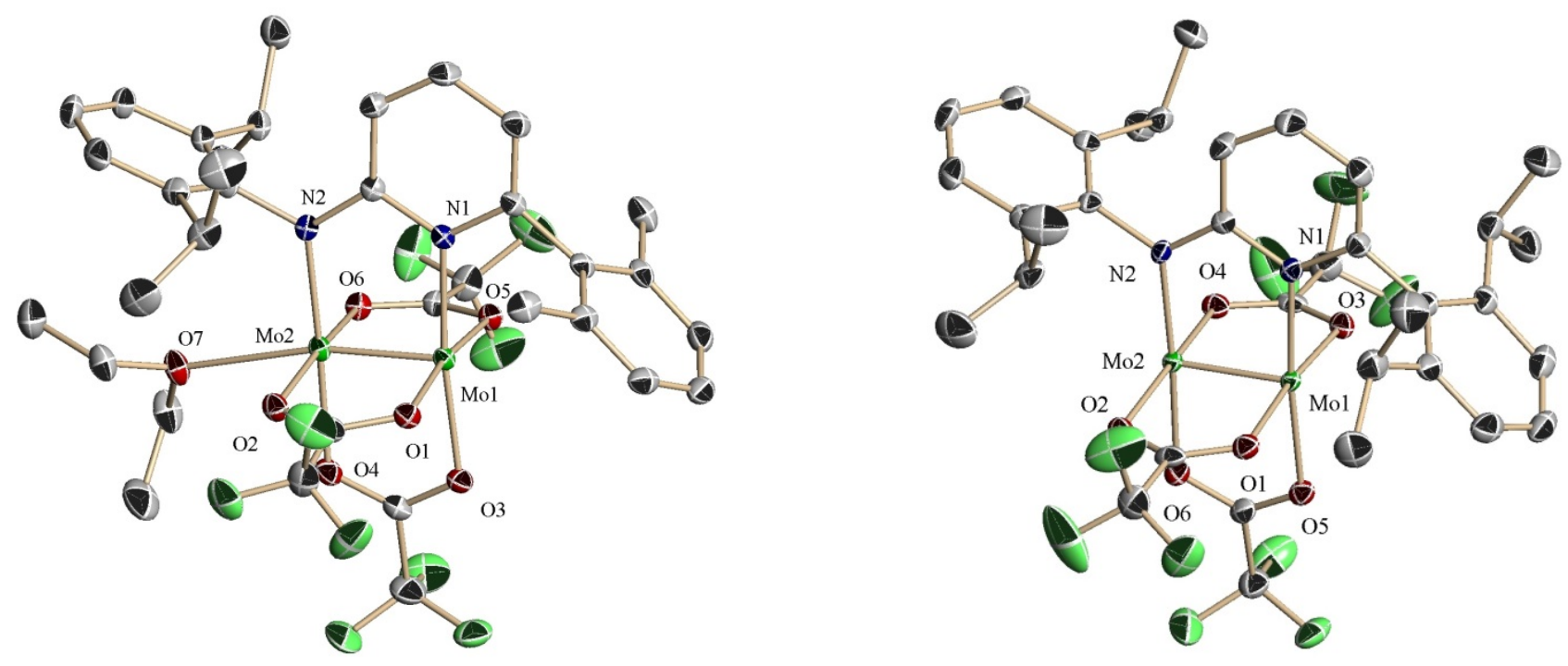

Fig. 3. The solid-state molecular structures of $\left[\mathrm{Mo}_{2}\left(\mu-\mathrm{O}_{2} \mathrm{CCF}_{3}\right)_{3}\left\{\mu-2-(\mathrm{NDipp})-6-(\mathrm{Xyl}) \mathrm{C}_{5} \mathrm{H}_{3} \mathrm{~N}\right\}\left(\mathrm{OEt}_{2}\right)\right]$, 1b (left) and $\left[\mathrm{Mo}_{2}\left(\mu-\mathrm{O}_{2} \mathrm{CCF}_{3}\right)_{3}\left\{\mu-2-(\mathrm{NDipp})-6-(\mathrm{Dipp}) \mathrm{C}_{5} \mathrm{H}_{3} \mathrm{~N}\right\}\right]$, 1c (right), with thermal ellipsoids set at $50 \%$ probability and all hydrogen atoms omitted for clarity. Selected bond lengths in $\AA$. 1b: $\operatorname{Mo}(1)-\operatorname{Mo}(2), 2.1104(3)$; $M o(1)-O(1), 2.118(2)$; Mo(1)-O(5), 2.120(2); Mo(1)-O(3), 2.133(2); Mo(2)-O(2), 2.124(2); Mo(2)-O(4), 2.181(2); Mo(2)-O(6), 2.131(3); $\mathrm{Mo}(2)-\mathrm{O}(7), 2.528(2) ; \mathrm{Mo}(1)-\mathrm{N}(1), 2.110(2) ; \mathrm{Mo}(2)-\mathrm{N}(2), 2.095(2)$. 1c: $\mathrm{Mo}(1)-\mathrm{Mo}(2), 2.1003(3) ; \mathrm{Mo}(1)-\mathrm{O}(1)$, 2.117(2); $\mathrm{Mo}(1)-\mathrm{O}(3), 2.122(2) ; \mathrm{Mo}(1)-\mathrm{O}(5), 2.136(2) ; \mathrm{Mo}(2)-\mathrm{O}(2), 2.111(2) ; \mathrm{Mo}(2)-\mathrm{O}(4), 2.111(2) ; \mathrm{Mo}(2)-\mathrm{O}(6)$, 2.163(2); Mo(1)-N(1), 2.118(2); $\mathrm{Mo}(2)-\mathrm{N}(2), 2.091(2)$.

The coordination environments of the two Mo atoms in the bis(aminopyridinate) complex $\mathbf{2 b}$ are identical and contain trans $\mathrm{N}_{\text {amido }}-\mathrm{Mo}-\mathrm{N}_{\mathrm{py}}$ arrays. This stereochemistry is the same found for the acetate analogues, $\left[\mathrm{Mo}_{2}(\mu-\mathrm{Ap})_{2}\left(\mu-\mathrm{O}_{2} \mathrm{CMe}\right)_{2}\right], 3$, to be discussed later. However, the crystals of 2c investigated 
present trans $\mathrm{N}_{\text {amido }}-\mathrm{Mo}-\mathrm{N}_{\mathrm{amido}}$ and $\mathrm{N}_{\mathrm{py}}-\mathrm{Mo}-\mathrm{N}_{\mathrm{py}}$ distributions (Fig. 4, right). Whereas there is no significant change in the Mo-Mo bond $(2.10 \AA)$ this stereochemistry introduces some noticeable differences in the metrical parameters that are evidenced in the observation of slightly shorter Mo- $\mathrm{N}_{\text {amido }}$ bonds (2.09 $\AA$ ) but distinctly longer Mo- $\mathrm{N}_{\mathrm{py}}$ distances of $c a .2 .23 \AA$. Most probably the weakening of the Mo- $\mathrm{N}_{\mathrm{py}}$ bonds is caused by the steric repulsions between the iso-propyl substituents of pyridyl bound aryl groups.

Our interest in bis(carboxylate) complexes analogous to 2 led us to investigate the reactivity of LiAp' towards $\left[\mathrm{Mo}_{2}\left(\mathrm{O}_{2} \mathrm{CMe}\right)_{4}\right]$. For the three aminopyridinate ligands, included in Scheme 1, the reaction between $\left[\mathrm{Mo}_{2}\left(\mathrm{O}_{2} \mathrm{CMe}\right)_{4}\right]$ and LiAp' in a 1:2 molar ratio provided the expected complexes $\left[\mathrm{Mo}_{2}(\mu-\mathrm{Ap})_{2}\left(\mu-\mathrm{O}_{2} \mathrm{CMe}\right)_{2}\right]$, 3a-3c, in good isolated yields (75-90\%). Somewhat surprisingly, while complex 3b features solubility properties similar to those of the trifluoroacetate analogues $\mathbf{2}$, compounds $\mathbf{3 a}$ and $\mathbf{3 c}$ are sparingly soluble in hydrocarbon and ether solvents (e.g. toluene or THF) and were crystallized by cooling slowly their hot solutions in toluene. The three complexes exhibit comparable NMR properties (see SI) which are in accordance with a trans geometry of $C_{2 \mathrm{~h}}$ molecular symmetry. Taking compound $\mathbf{3 b}$ as a representative example, its two aryl methyl substituents give a ${ }^{1} \mathrm{H}$ NMR singlet with $\delta 2.06$ (relative intensity $12 \mathrm{H}$ ) and similarly only one septet and two doublets $(3.38,4 \mathrm{H} ; 1.16$ and $1.21,12 \mathrm{H}: 12 \mathrm{H}$, respectively) are recorded for the iso-propyl substituents of the aryl group bonded to the $\mathrm{N}_{\text {amido }}$ functionality.
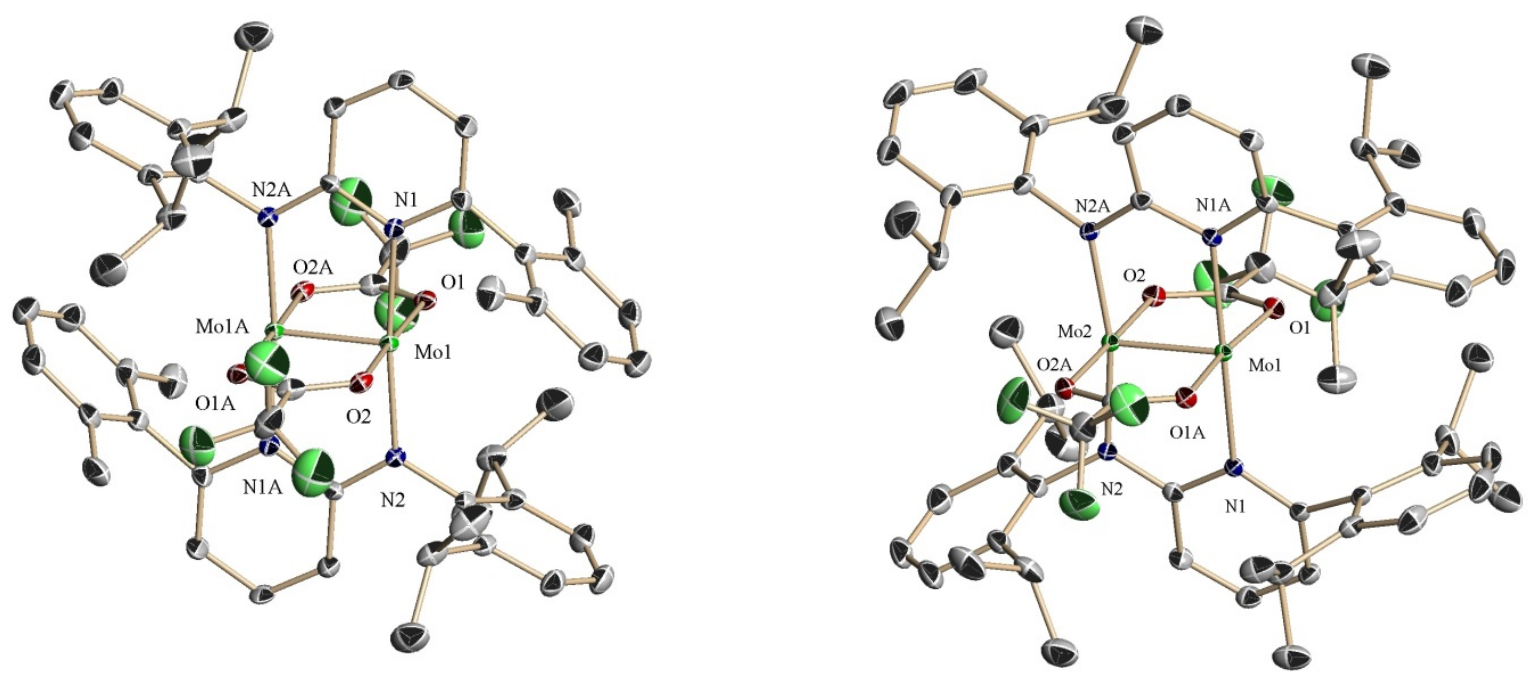

Fig. 4. The solid-state molecular structures of $\left[\mathrm{Mo}_{2}\left(\mu-\mathrm{O}_{2} \mathrm{CCF}_{3}\right)_{2}\left\{\mu-2-(\mathrm{NDipp})-6-(\mathrm{Xyl}) \mathrm{C}_{5} \mathrm{H}_{3} \mathrm{~N}\right\}_{2}\right], 2 \mathbf{b}$ (left) and $\left[\mathrm{Mo}_{2}\left(\mu-\mathrm{O}_{2} \mathrm{CCF}_{3}\right)_{2}\left\{\mu-2-(\mathrm{NDipp})-6-(\mathrm{Dipp}) \mathrm{C}_{5} \mathrm{H}_{3} \mathrm{~N}\right\}_{2}\right], 2 \mathrm{c}$ (right), with thermal ellipsoids set at $50 \%$ probability and all hydrogen atoms omitted for clarity. Selected bond lengths in $\AA$. 2b: $\operatorname{Mo}(1)-\operatorname{Mo}(1 \mathrm{~A})$, 2.098(1); $\mathrm{Mo}(1)-\mathrm{N}(1), 2.157(4) ; \mathrm{Mo}(1)-\mathrm{N}(2), 2.125(4)$; $\mathrm{Mo}(1)-\mathrm{O}(1), 2.123(3)$; $\mathrm{Mo}(1)-\mathrm{O}(2), 2.129(3) .2 \mathrm{c}:$ $\mathrm{Mo}(1)-\mathrm{Mo}(2), \quad 2.0915(4) ; \quad \mathrm{Mo}(1)-\mathrm{O}(1), \quad 2.114(1) ; \quad \mathrm{Mo}(2)-\mathrm{O}(2), \quad 2.136(1) ; \quad \mathrm{Mo}(1)-\mathrm{N}(1), \quad 2.215(2)$; Mo(2)-N(2), 2.095(2). An inversion center located at the midpoint of the Mo-Mo bond and a two-fold 
crystallographic axis along the Mo-Mo bonds are used to generate equivalent atoms for $\mathbf{2 b}$ and $2 \mathbf{c}$, respectively.

The three acetate complexes 3 were subjected to X-ray studies. Fig. 5 contains ORTEP representations of their molecular structure, which as briefly anticipated is similar to that of the trifluoroacetate $\mathbf{2 b}$. Therefore, for these compounds the $\mathrm{N}_{\text {amido }}$ nitrogen atom of each of the aminopyridinate groups places itself in a trans position relative to the $\mathrm{N}_{\text {py }}$ atom of the other, sustaining in this manner a Mo $\equiv$ Mo bond with length ca. 2.09 $\AA$. In the molecules of $3 \mathbf{a}-\mathbf{c}$ the $\mathrm{Mo}-\mathrm{N}_{\mathrm{py}}$ bonds are slightly longer than the Mo- $\mathrm{N}_{\text {amido }}$ bonds with differences of $0.02-0.05 \AA$.

With the aim of widening the scope of this work on aminopyridinate complexes of $\mathrm{M}_{2}^{\mathrm{II}}$ cores, we also carried out the reaction of $\left[\mathrm{W}_{2}\left(\mathrm{O}_{2} \mathrm{CCF}_{3}\right)_{4}\right]$ with LiAp' in a 1:2 molar ratio employing the Ap' ligand with 2,6- $-\mathrm{Me}_{2}-\mathrm{C}_{6} \mathrm{H}_{3}$ and 2,6-i- $\mathrm{Pr}_{2}-\mathrm{C}_{6} \mathrm{H}_{3}$ substituents to obtain the desired $\left[\mathrm{W}_{2}(\mu-\mathrm{Ap})_{2}\left(\mu-\mathrm{O}_{2} \mathrm{CCF}_{3}\right)_{2}\right]$ product, $4 \mathbf{b}$. The new complex gives rise to only one ${ }^{19} \mathrm{~F}$ NMR resonance with chemical shift $-76.9 \mathrm{ppm}$ and features ${ }^{1} \mathrm{H}$ and ${ }^{13} \mathrm{C}\left\{{ }^{1} \mathrm{H}\right\}$ NMR properties that are similar to those of the molybdenum analogue $2 \mathbf{b}$ (and also of $\mathbf{3 b}$ ). Even if crystals of $\mathbf{4 b}$ suitable for an X-ray study could not be obtained, it seems reasonable to propose a structure akin to that of the homologous complex $\mathbf{2} \mathbf{b}$.
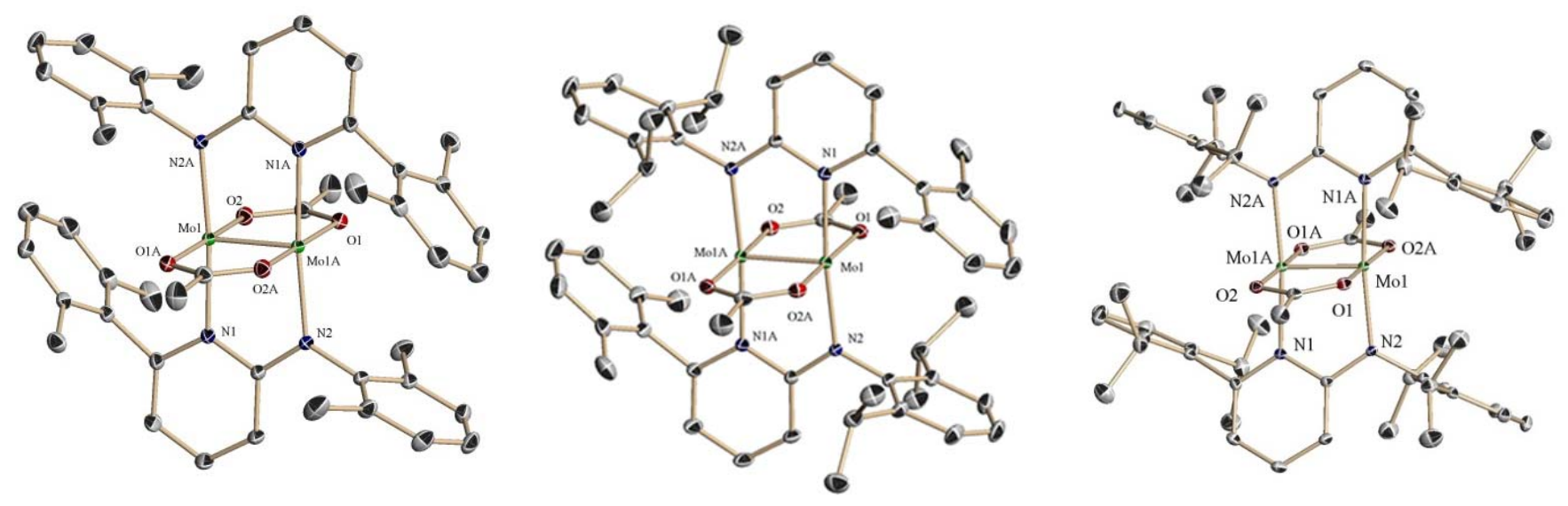

Fig. 5. The solid-state molecular structures of $\left[\mathrm{Mo}_{2}\left(\mu-\mathrm{O}_{2} \mathrm{CMe}\right)_{2}\left\{\mu-2-(\mathrm{NXyl})-6-(\mathrm{Xyl}) \mathrm{C}_{5} \mathrm{H}_{3} \mathrm{~N}\right\}_{2}\right]$, 3a (left) and $\left[\mathrm{Mo}_{2}\left(\mu-\mathrm{O}_{2} \mathrm{CMe}\right)_{2}\left\{\mu-2-(\mathrm{NDipp})-6-(\mathrm{Xyl}) \mathrm{C}_{5} \mathrm{H}_{3} \mathrm{~N}\right\}_{2}\right], \quad 3 \mathbf{b} \quad$ (centre) and $\quad\left[\mathrm{Mo}_{2}\left(\mu-\mathrm{O}_{2} \mathrm{CMe}\right)_{2}\{\mu-2-(\mathrm{NDipp})-6-\right.$ (Dipp) $\left.\mathrm{C}_{5} \mathrm{H}_{3} \mathrm{~N}\right\}_{2}$ ], 3c (right), with thermal ellipsoids set at 50\% probability and all hydrogen atoms omitted for clarity. Selected bond lengths in $\AA$. 3a: $\mathrm{Mo}(1)-\mathrm{Mo}(1 \mathrm{~A}), 2.0884(1) ; \operatorname{Mo}(1)-\mathrm{N}(1), 2.153(1)$; $\mathrm{Mo}(1 \mathrm{~A})-\mathrm{N}(2)$, 2.133(1); $\mathrm{Mo}(1)-\mathrm{O}(1 \mathrm{~A}), 2.115(1)$; $\mathrm{Mo}(1)-\mathrm{O}(2), 2.118(1)$. 3b: $\mathrm{Mo}(1)-\mathrm{Mo}(1 \mathrm{~A}), 2.0893(2) ; \operatorname{Mo}(1)-\mathrm{N}(1)$, 2.160(2); $\mathrm{Mo}(1)-\mathrm{N}(2), 2.134(2) ; \operatorname{Mo}(1)-\mathrm{O}(1), 2.112(2) ; \operatorname{Mo}(1)-\mathrm{O}(2 \mathrm{~A}), 2.119(2)$. 3c: $\mathrm{Mo}(1)-\mathrm{Mo}(1 \mathrm{~A})$, 2.0857(2); $\mathrm{Mo}(1 \mathrm{~A})-\mathrm{N}(1), 2.167(1) ; \mathrm{Mo}(1)-\mathrm{N}(2), 2.116(1) ; \mathrm{Mo}(1)-\mathrm{O}(1), 2.106(1) ; \mathrm{Mo}(1)-\mathrm{O}(2 \mathrm{~A}), 2.114(1)$. For structures 3a-c, a crystallographic inversion center located at the midpoint of the Mo-Mo bond is used to generate equivalent atoms. 


\subsection{Amidinate Complexes}

Recent work from our group has resulted in the structural characterization of bis(amidinate) complexes of molybdenum with composition $\left[\mathrm{Mo}_{2}\left\{\mu-\mathrm{HC}\left(\mathrm{N}-2,6-i \mathrm{Pr}_{2}-\mathrm{C}_{6} \mathrm{H}_{3}\right)_{2}\right\}_{2}\left(\mu-\mathrm{O}_{2} \mathrm{CR}\right)_{2}\right]$, for $\mathrm{R}=\mathrm{H}$, Me. Of these, the acetate has proven of utility as a precursor of various dimolybdenum complexes with quadruple and quintuple M-M bonds [18].

Parallel to the above studies, we carried out the reactions of $\left[\mathrm{M}_{2}\left(\mathrm{O}_{2} \mathrm{CCF}_{3}\right)_{4}\right](\mathrm{M}=\mathrm{Mo}$, W) with one or two equivalents of $\mathrm{Li}\left\{\mathrm{HC}\left(\mathrm{N}-2,6-i \mathrm{Pr}_{2}-\mathrm{C}_{6} \mathrm{H}_{3}\right)_{2}\right\}_{2}$ and obtained the complexes $\left[\mathrm{Mo}_{2}\left\{\mu-\mathrm{HC}\left(\mathrm{N}-2,6-i \mathrm{Pr}_{2}-\right.\right.\right.$ $\left.\left.\left.\mathrm{C}_{6} \mathrm{H}_{3}\right)_{2}\right\}\left(\mu-\mathrm{O}_{2} \mathrm{CR}\right)_{3}\right], 5$, and $\left[\mathrm{W}_{2}\left\{\mu-\mathrm{HC}\left(\mathrm{N}-2,6-i \mathrm{Pr}_{2}-\mathrm{C}_{6} \mathrm{H}_{3}\right)_{2}\right\}_{2}\left(\mu-\mathrm{O}_{2} \mathrm{CR}\right)_{2}\right]$, 6. The spectroscopic data recorded for these species are similar to those already discussed for the other complexes reported in this paper. They are collected in the SI and need no further analysis.

Fig. 6 and 7 contain ORTEP representations of their molecular structures. In the molybdenum complex 5 there are two molecules of THF in axial positions weakly bonded to the Mo atoms (Mo-O distances of 2.59 and $2.53 \AA$ ), while in the tungsten complex 6 there is only one molecule at a shorter W-O distance of $2.45 \AA$. In the $\mathrm{Mo}_{2}{ }_{2}$ complex the Mo-Mo bond has a length of $2.11 \AA$ which compares well with corresponding values in compounds 1 and 2 (2.10 $\AA$ ). In turn, the ditungsten complex 6 features a W-W bond with length $2.22 \AA$. This value is identical within experimental error to the $2.20 \AA$ distance found for the recently reported terphenyl derivative $\left[\mathrm{W}_{2}\left(\mathrm{Ar}^{\prime}\right)_{2}\left(\mu-\mathrm{O}_{2} \mathrm{CCF}_{3}\right)_{2}\right]\left(\mathrm{Ar}{ }^{\prime}=\right.$ terphenyl ligand $)[17 \mathrm{~b}]$ and it is also comparable to $\mathrm{W}-\mathrm{W}$ distances found for other $\mathrm{W}_{2}^{\mathrm{II}}$ complexes described in the literature [2].

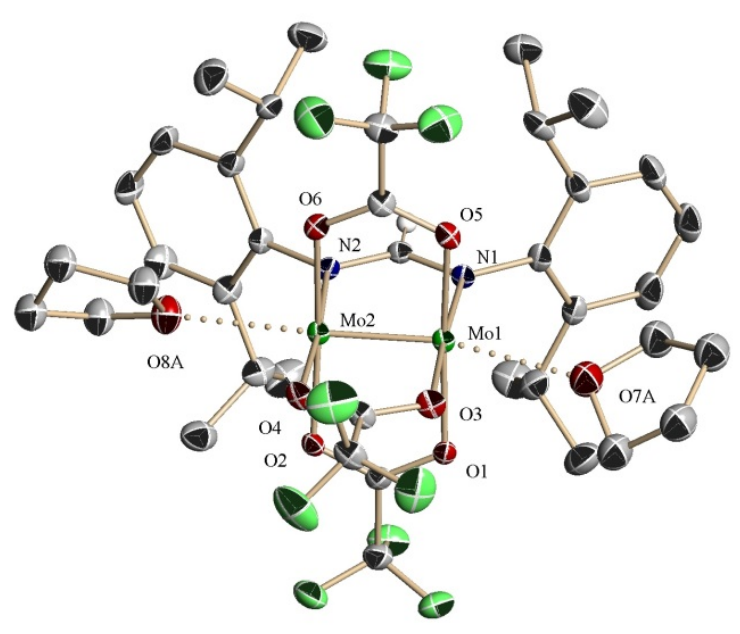

Fig. 6. The solid-state molecular structures of $\left[\mathrm{Mo}_{2}\left(\mu-\mathrm{O}_{2} \mathrm{CCF}_{3}\right)_{3}\left\{\mu-\mathrm{HC}\left(\mathrm{N}-2,6-\mathrm{Pr}_{2} \mathrm{C}_{6} \mathrm{H}_{3}\right)_{2}\right\}(\mathrm{THF})_{2}\right]$, 5, with thermal ellipsoids set at 50\% probability and all hydrogen atoms omitted for clarity. Selected bond lengths in $\AA$ : $\operatorname{Mo}(1)-\operatorname{Mo}(2)$, 2.1147(7); $\mathrm{Mo}(1)-\mathrm{N}(1), 2.108(4) ; \mathrm{Mo}(2)-\mathrm{N}(2), 2.107(4) ; \mathrm{Mo}(1)-\mathrm{O}(1), 2.133(4) ; \mathrm{Mo}(1)-\mathrm{O}(3), 2.172(3) ; \mathrm{Mo}(1)-\mathrm{O}(7)$, 2.536(5); $\mathrm{Mo}(2)-\mathrm{O}(2), 2.118(3) ; \mathrm{Mo}(2)-\mathrm{O}(4), 2.165(3) ; \mathrm{Mo}(2)-\mathrm{O}(6), 2.126(3) ; \mathrm{Mo}(2)-\mathrm{O}(8), 2.597(4)$. 


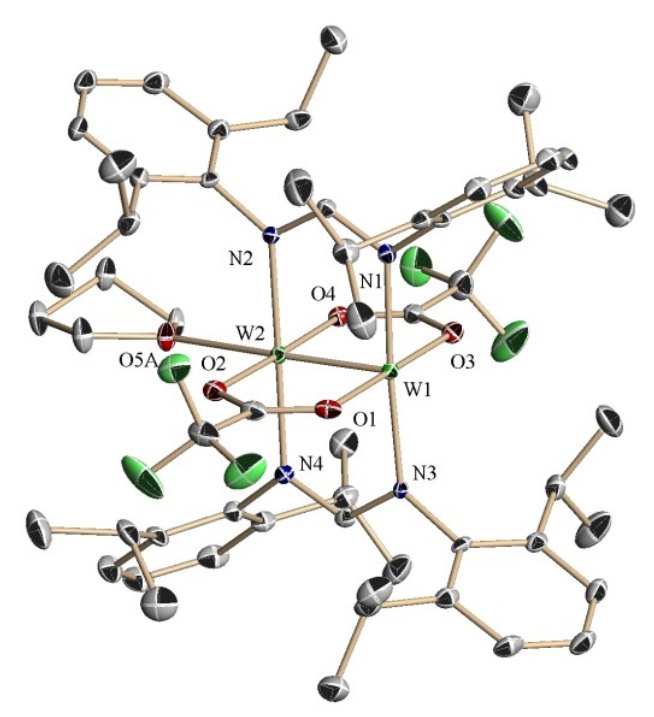

Fig. 7. The solid-state molecular structures of $\left[\mathrm{W}_{2}\left(\mu-\mathrm{O}_{2} \mathrm{CCF}_{3}\right)_{2}\left\{\mu-\mathrm{HC}\left(\mathrm{N}-2,6-i \mathrm{Pr}_{2} \mathrm{C}_{6} \mathrm{H}_{3}\right)_{2}\right\}_{2}(\mathrm{THF})\right]$, 6, with thermal ellipsoids set at 50\% probability and all hydrogen atoms omitted for clarity. Selected bond lengths in $\AA$ : W(1)-W(2), 2.217(1); W(1)-N(1), 2.123(2); W(1)-N(3), 2.117(2); W(1)-O(1), 2.090(2); W(1)-O(3), 2.089(2); W(2)-N(2), 2.143(2); W(2)-N(4), 2.144(2); W(2)-O(2), 2.078(2); W(2)-O(4), 2.089(2); W(2)-O(5A), 2.45(1).

In summary, by the use of bridging aminopyridinate and amidinate ligands, we have prepared several molybdenum and tungsten complexes of general composition $\left[\mathrm{M}_{2}(\widetilde{\mathrm{N} \mathrm{N}})\left(\mathrm{O}_{2} \mathrm{CR}\right)_{3}\right]$ and $\left[\mathrm{M}_{2}(\widetilde{\mathrm{N} \mathrm{N}})_{2}\left(\mathrm{O}_{2} \mathrm{CR}\right)_{2}\right]$ that feature quadruple metal-metal bonds. We are currently studying the utility of some of these complexes for the synthesis of low-coordinate dimolybdenum and ditungsten complexes with multiple metal-metal bonds. 
Table 1.

Crystal data and experimental details for all complexes.

\begin{tabular}{|c|c|c|c|c|c|c|c|c|c|}
\hline Parameter & $1 \mathrm{~b}$ & $1 \mathrm{c}$ & $2 \mathrm{~b} \cdot \mathrm{OEt}_{2}$ & $2 \mathrm{c} \cdot \mathrm{C}_{6} \mathrm{H}_{14}$ & $3 a$ & $3 b \cdot \mathrm{OEt}_{2}$ & $3 c$ & 5.THF & 6 \\
\hline Formula & $\mathrm{C}_{35} \mathrm{H}_{39} \mathrm{~F}_{9} \mathrm{Mo}_{2} \mathrm{~N}_{2} \mathrm{O}_{7}$ & $\mathrm{C}_{35} \mathrm{H}_{37} \mathrm{~F}_{9} \mathrm{Mo}_{2} \mathrm{~N}_{2} \mathrm{O}_{6}$ & $\mathrm{C}_{58} \mathrm{H}_{68} \mathrm{~F}_{6} \mathrm{Mo}_{2} \mathrm{~N}_{4} \mathrm{O}_{5}$ & $\mathrm{C}_{68} \mathrm{H}_{88} \mathrm{~F}_{6} \mathrm{Mo}_{2} \mathrm{~N}_{4} \mathrm{O}_{4}$ & $\mathrm{C}_{46} \mathrm{H}_{48} \mathrm{Mo}_{2} \mathrm{~N}_{4} \mathrm{O}_{4}$ & $\mathrm{C}_{58} \mathrm{H}_{74} \mathrm{Mo}_{2} \mathrm{~N}_{4} \mathrm{O}_{5}$ & $\mathrm{C}_{62} \mathrm{H}_{80} \mathrm{Mo}_{2} \mathrm{~N}_{4} \mathrm{O}_{4}$ & $\mathrm{C}_{43} \mathrm{H}_{59} \mathrm{~F}_{9} \mathrm{Mo}_{2} \mathrm{~N}_{2} \mathrm{O}_{9}$ & $\mathrm{C}_{58} \mathrm{H}_{78} \mathrm{~F}_{6} \mathrm{~N}_{4} \mathrm{O}_{5} \mathrm{~W}_{2}$ \\
\hline$T(K)$ & $173(2)$ & $100(2)$ & $173(2)$ & $173(2)$ & $100(2)$ & $173(2)$ & $293(2)$ & $173(2)$ & $100(2)$ \\
\hline Crystal system & Monoclinic & Monoclinic & Monoclinic & Monoclinic & Triclinic & Triclinic & Monoclinic & Orthorhombic & Monoclinic \\
\hline Space group & $\mathrm{P} 2_{1} / \mathrm{n}$ & $\mathrm{P} 22_{1} / \mathrm{c}$ & $\mathrm{C} 2 / \mathrm{c}$ & $\mathrm{C} 2 / \mathrm{c}$ & $\mathrm{P} \overline{1}$ & $\mathrm{P} \overline{1}$ & $\mathrm{P} 2_{1} / \mathrm{n}$ & $\mathrm{Pbcn}$ & $\mathrm{P} 2_{1} / \mathrm{c}$ \\
\hline \multicolumn{10}{|l|}{ Unit cell parameters } \\
\hline$a(\AA)$ & $10.7675(4)$ & $12.1583(6)$ & $21.516(10)$ & $22.0604(11)$ & $9.6189(2)$ & $11.1913(5)$ & $11.8100(4)$ & $32.864(4)$ & $13.1770(6)$ \\
\hline$b(\AA ̊)$ & $22.9228(10)$ & $16.7986(8)$ & $11.795(5)$ & $13.6420(6)$ & $10.2292(2)$ & $12.1888(5)$ & $17.5000(5)$ & $16.0484(18)$ & $19.7669(8)$ \\
\hline$c(\AA ̊)$ & $16.9966(7)$ & $18.7477(10)$ & $22.894(10)$ & $23.0026(10)$ & $12.1372(3)$ & $12.4422(6)$ & $14.5900(4)$ & $18.474(2)$ & $22.1187(9)$ \\
\hline$V\left(\AA^{3}\right)$ & $4004.7(3)$ & $3816.2(3)$ & $5657(4)$ & $6596.3(5)$ & $1049.82(4)$ & $1381.45(11)$ & $2894.04(15)$ & $9743.8(19)$ & $5583.4(4)$ \\
\hline$\alpha\left({ }^{\circ}\right)$ & 90 & 90 & 90 & 90 & $109.5150(10)$ & $89.500(2)$ & 90 & 90 & 90 \\
\hline$\beta\left(^{\circ}\right)$ & 107.3270(10) & $94.692(2)$ & 103.191(17) & $107.660(2)$ & $94.1570(10)$ & $66.0970(10)$ & $106.31(10)$ & 90 & $104.274(2)$ \\
\hline$\gamma\left({ }^{\circ}\right)$ & 90 & 90 & 90 & 90 & $107.9920(10)$ & $65.1800(10)$ & 90 & 90 & 90 \\
\hline$z$ & 4 & 4 & 4 & 4 & 1 & 1 & 2 & 8 & 4 \\
\hline$D_{\text {calc }}\left(\mathrm{g} \mathrm{cm}^{-3}\right)$ & 1.596 & 1.644 & 1.417 & 1.341 & 1.444 & 1.321 & 1.305 & 1.514 & 1.657 \\
\hline$\mu_{\mathrm{Mo}}\left(\mathrm{mm}^{-1}\right)$ & 0.715 & 0,747 & 0.513 & 0.446 & 0.645 & 0.503 & 0.482 & 0.602 & 4.189 \\
\hline$F(000)$ & 1936 & 1896 & 2488 & 2776 & 468 & 574 & 1192 & 4544 & 2784 \\
\hline$\theta_{\max }\left({ }^{\circ}\right)$ & $1.54-25.25$ & $1.63-25.25$ & $1.94-25.25$ & $1.78-25.25$ & $1.82-36.32$ & $1.83-25.25$ & $1.86-30.65$ & $2.09-25.25$ & $1.40-30.69$ \\
\hline \multirow[t]{3}{*}{ Index ranges } & $-8 \leq h \leq 12$ & $-14 \leq h \leq 14$ & $-17 \leq \mathrm{h} \leq 25$ & $-25 \leq \mathrm{h} \leq 26$ & $-15 \leq h \leq 13$ & $-13 \leq h \leq 12$ & $-16 \leq h \leq 16$ & $-39 \leq h \leq 39$ & $-18 \leq h \leq 18$ \\
\hline & $-27 \leq k \leq 27$ & $-18 \leq k \leq 20$ & $-13 \leq k \leq 14$ & $-16 \leq k \leq 14$ & $-14 \leq k \leq 16$ & $-14 \leq k \leq 13$ & $-25 \leq k \leq 25$ & $-19 \leq k \leq 19$ & $-28 \leq k \leq 28$ \\
\hline & $-20 \leq I \leq 14$ & $-18 \leq 1 \leq 22$ & $-25 \leq 1 \leq 27$ & $-25 \leq 1 \leq 27$ & $-20 \leq 1 \leq 18$ & $-14 \leq 1 \leq 12$ & $-20 \leq 1 \leq 15$ & $-22 \leq 1 \leq 12$ & $-31 \leq 1 \leq 31$ \\
\hline Reflections measured/ reflections & $40481 / 7176$ & $16183 / 6849$ & $22329 / 5081$ & $77746 / 5969$ & $25085 / 8115$ & $25100 / 4953$ & $33850 / 8870$ & $88692 / 8820$ & $61277 / 17248$ \\
\hline independent & {$\left[R_{\text {int }}=0.0282\right]$} & {$\left[R_{\text {int }}=0.0203\right]$} & {$\left[R_{\text {int }}=0.0914\right]$} & {$\left[R_{\text {int }}=0.0361\right]$} & {$\left[R_{\text {int }}=0.0234\right]$} & {$\left[R_{\text {int }}=0.0301\right]$} & {$\left[R_{\text {int }}=0.0335\right]$} & {$\left[R_{\text {int }}=0.0951\right]$} & {$\left[R_{\text {int }}=0.0649\right]$} \\
\hline Parameters & 585 & 495 & 373 & 389 & 258 & 341 & 334 & 711 & 728 \\
\hline Goodness-of-fit on F2 & 1.052 & 1.179 & 0.909 & 1.101 & 1.032 & 1.045 & 0.859 & 1.076 & 0.928 \\
\hline \multirow[t]{2}{*}{ Final $R$ indices $[\mid>2 \sigma(I)]$} & $R_{1}=0.0262$ & $R_{1}=0.0276$ & $R_{1}=0.0532$ & $R_{1}=0.0309$ & $R_{1}=0.0243$ & $\mathrm{R}_{1}=0.0233$ & $\mathrm{R}_{1}=0.0284$ & $R_{1}=0.0628$ & $R_{1}=0.0305$ \\
\hline & $w R_{2}=0.0656$ & $\mathrm{wR}_{2}=0.0607$ & $\mathrm{wR}_{2}=0.1121$ & $\mathrm{wR}_{2}=0.0781$ & $\mathrm{wR}_{2}=0.0639$ & $w R_{2}=0.0592$ & $w R_{2}=0.0684$ & $w R_{2}=0.1615$ & $\mathrm{wR}_{2}=0.0786$ \\
\hline Largest diff. peak and hole (e $\AA^{3}$ ) & 0.708 and -0.423 & 0.586 and -0.430 & 1.013 and -1.154 & 0.727 and -0.570 & 1.143 and -0.855 & 0.799 and -0.428 & 0.854 and -0.489 & 1.374 and -2.508 & 3.768 and -2.178 \\
\hline
\end{tabular}




\section{Experimental}

\subsection{General procedures}

All manipulations were carried out using standard Schlenk and glove-box techniques, under an atmosphere of argon and of high purity nitrogen, respectively. All solvents were dried and degassed prior to use, and stored over $4 \AA$ molecular sieves. Toluene $\left(\mathrm{C}_{7} \mathrm{H}_{8}\right), n$-pentane $\left(\mathrm{C}_{5} \mathrm{H}_{12}\right)$ and $n$-hexane $\left(\mathrm{C}_{6} \mathrm{H}_{14}\right)$ were distilled under nitrogen over sodium. Tetrahydrofuran (THF) and diethyl ether were distilled under nitrogen over sodium/benzophenone. $\left[\mathrm{D}_{6}\right]$ Benzene and $\left[\mathrm{D}_{8}\right]$ THF were distilled under argon over sodium/benzophenone; $\left[\mathrm{D}_{8}\right]$ toluene was distilled under argon over sodium. The quadruply bonded $\left[\mathrm{M}_{2}\left(\mathrm{O}_{2} \mathrm{CR}\right)_{4}\right]\left(\mathrm{M}=\mathrm{Mo}, \mathrm{R}=\mathrm{CH}_{3}, \mathrm{CF}_{3} ; \mathrm{M}=\mathrm{W}, \mathrm{R}=\mathrm{CF}_{3}\right)$ complexes [22-24], as well as the different aminopyridine $\left\{2-\mathrm{NH}(\mathrm{Xyl})-6-(\mathrm{Xyl}) \mathrm{C}_{5} \mathrm{H}_{3} \mathrm{~N}\right\},\left\{2-\mathrm{NH}\left(\right.\right.$ Dipp)-6-(Xyl) $\left.\mathrm{C}_{5} \mathrm{H}_{3} \mathrm{~N}\right\},\left\{2-\mathrm{NH}\left(\right.\right.$ Dipp)-6-(Dipp) $\left.\mathrm{C}_{5} \mathrm{H}_{3} \mathrm{~N}\right\}$ (abbreviated Ap'H, with Dipp = 2,6-i $\mathrm{Pr}_{2} \mathrm{C}_{6} \mathrm{H}_{3}$ and $\left.\mathrm{Xyl}=2,6-\mathrm{Me}_{2} \mathrm{C}_{6} \mathrm{H}_{3}\right)$ [20] and formamidine $\mathrm{H}\{\mathrm{HC}(\mathrm{N}-2,6-$ $\left.\left.i \mathrm{Pr}_{2} \mathrm{C}_{6} \mathrm{H}_{3}\right)_{2}\right\}$ [25] ligands, and their corresponding lithium salts LiAp' [20] and Li\{HC(N-2,6$\left.\left.i \mathrm{Pr}_{2} \mathrm{C}_{6} \mathrm{H}_{3}\right)_{2}\right\}(\mathrm{THF})_{2}$, [26] were prepared according to literature methods. $\left[\mathrm{Mo}_{2}\left(\mathrm{O}_{2} \mathrm{CMe}\right)_{4}\right]$ was washed with toluene at $100{ }^{\circ} \mathrm{C}$ to remove any acidic residue. All other compounds were commercially available and were used as received. Solution NMR spectra were recorded on Bruker AMX-300, DRX-400 and DRX-500 spectrometers. The resonance of the solvent was used as the internal standard, chemical shifts are reported relative to TMS and the NMR signals of fluorinated derivatives are reported relative to $\mathrm{CFCl}_{3}$. $\mathrm{UV}$-visible spectra were recorded on a PerkinElmer Lambda 750 spectrometer. IR spectra were recorded on a Bruker Tensor 27 and for elemental analyses a LECO TruSpec CHN elementary analyzer, was utilized.

\subsection{Preparation of trifluoroacetate mono- and bis-aminopyridinate dimolybdenum complexes 1 and 2.}

\subsubsection{Synthesis of $\left[\mathrm{Mo}_{2}\left(\mu-\mathrm{O}_{2} \mathrm{CCF}_{3}\right)_{3}\left\{\mu-2-(N D i p p)-6-(X y l) C_{5} \mathrm{H}_{3} N\right\}\right]$, (1b).}

The reagents $\left[\mathrm{Mo}_{2}\left(\mathrm{O}_{2} \mathrm{CCF}_{3}\right)_{4}\right](515 \mathrm{mg}, 0.80 \mathrm{mmol})$ and $\left\{\mathrm{Li}\left(2-(\mathrm{NDipp})-6-(\mathrm{Xyl}) \mathrm{C}_{5} \mathrm{H}_{3} \mathrm{~N}\right)\right\}_{2}\left(\mathrm{OEt}_{2}\right)(321 \mathrm{mg}$, $0.40 \mathrm{mmol}$ ) were placed in a Young ampoule inside the dry box. The reaction flask was then cooled to -40 ${ }^{\circ} \mathrm{C}$ and $20 \mathrm{~mL}$ of diethyl ether was added. The reaction mixture was allowed to reach room temperature with continuous stirring during 12 hours. Then, the solvent was removed under vacuum and the solid residue was extracted with $20 \mathrm{~mL}$ of pentane. The filtrate was transferred to a Schlenk tube, concentrated to a volume of ca. $5 \mathrm{~mL}$, and stored at $-23{ }^{\circ} \mathrm{C}$ to obtain yellow crystals suitable for X-ray diffraction, which were collected by filtration and dried under vacuum in a ca. $60 \%$ yield (430 mg). Anal. Calcd. for $\mathrm{C}_{31} \mathrm{H}_{29} \mathrm{~F}_{9} \mathrm{Mo}_{2} \mathrm{~N}_{2} \mathrm{O}_{6}: \mathrm{C}_{\text {, }}$ 41.91; H, 3.29; N, 3.15. Found: C, 41.7; H, 3.6; N, 3.0. ${ }^{1} \mathbf{H}$ NMR $\left(500 \mathrm{MHz}, \mathrm{C}_{6} \mathrm{D}_{6}, 25{ }^{\circ} \mathrm{C}\right): \delta=1.09,1.31(\mathrm{~d}$, $6 \mathrm{H}$ each, $\left.{ }^{3} J_{\mathrm{HH}}=6.8 \mathrm{~Hz}, 2 \mathrm{Me}_{\text {Dipp }}\right), 1.96\left(\mathrm{~s}, 6 \mathrm{H}, 2 \mathrm{Me}_{\mathrm{Xyl}}\right), 2.82\left(\mathrm{sept}, 2 \mathrm{H},{ }^{3} \mathrm{~J}_{\mathrm{HH}}=6.8 \mathrm{~Hz}, 2 \mathrm{CHMe}\right), 5.85(\mathrm{dd}$, $\left.1 \mathrm{H},{ }^{3} J_{\mathrm{HH}}=6.8 \mathrm{~Hz},{ }^{4} J_{\mathrm{HH}}=1.0 \mathrm{~Hz}, 5-\mathrm{py}\right), 6.41\left(\mathrm{dd}, 1 \mathrm{H},{ }^{3} J_{\mathrm{HH}}=9.1 \mathrm{~Hz},{ }^{4} J_{\mathrm{HH}}=1.0 \mathrm{~Hz}, 3-\mathrm{py}\right), 6.51\left(\mathrm{~m}, 3 \mathrm{H}, \mathrm{AB}_{2}\right.$ system, $m$-Xyl and p-Xyl), $6.78\left(\mathrm{dd}, 1 \mathrm{H},{ }^{3} J_{\mathrm{HH}}=9.1 \mathrm{~Hz},{ }^{3} J_{\mathrm{HH}}=6.8 \mathrm{~Hz}, 4-\mathrm{py}\right), 7.12\left(\mathrm{~m}, 3 \mathrm{H}, \mathrm{AB}_{2}\right.$ system, $m$ -

Dipp and $p$-Dipp) ppm. ${ }^{13} \mathbf{C}\left\{{ }^{1} \mathbf{H}\right\}$ NMR $\left(125 \mathrm{MHz}, \mathrm{C}_{6} \mathrm{D}_{6}, 25{ }^{\circ} \mathrm{C}\right): \delta=19.6\left(\mathrm{Me}_{\mathrm{Xyl}}\right), 24.3,25.6\left(\mathrm{Me}_{\text {Dipp }}\right), 28.2$ 
(CHMe $)$ ), 108.2 (5-py), 112.0 (3-py), 125.1 (m-Dipp), 127.9-128.5 (under $\mathrm{C}_{6} \mathrm{D}_{6}$ signal, $p$-Dipp and $m$-Xyl), 129.8 (p-Xyl), 135.3 (4-py), 137.2 (o-Xyl), 146.1 (o-Dipp), 153.4 (6-py), 169.2 (2-py) ppm. Resonances due to the trifluoroacetate groups, ipso-Xyl and ipso-Dipp were not detected. ${ }^{19} \mathbf{F}\left\{{ }^{1} \mathbf{H}\right\} \mathbf{N M R}\left(376.5 \mathrm{MHz}, \mathrm{C}_{6} \mathrm{D}_{6}\right.$, $\left.25^{\circ} \mathrm{C}\right): \delta=-72.9\left(3 \mathrm{~F},\left(\mathrm{O}_{2} \mathrm{CCF}_{3}\right)_{\text {trans }}\right),-72.6\left(6 \mathrm{~F}, \mathrm{O}_{2} \mathrm{CCF}_{3}\right) \mathrm{ppm}$. IR (nujol): $v_{\text {as }}(\mathrm{OCO}) 1610, v_{\text {as }}(\mathrm{C}-\mathrm{F}) 1190$, $v(\mathrm{C}-\mathrm{C}) 855, v_{\mathrm{d}}(\mathrm{OCO}) 780, v_{\mathrm{d}}\left(\mathrm{CF}_{3}\right) 730 \mathrm{~cm}^{-1}$. UV-visible (THF solution $\left.10^{-4} \mathrm{M}\right): \lambda=475 \mathrm{~nm}, \varepsilon=750$ $\mathrm{mol}^{-1} \mathrm{~L} \mathrm{~cm}^{-1}$.

\subsubsection{Synthesis of $\left[\mathrm{Mo}_{2}\left(\mu-\mathrm{O}_{2} \mathrm{CCF}_{3}\right)_{3}\left\{\mu-2-(N D i p p)-6-(D i p p) C_{5} H_{3} N\right\}\right]$, (1c).}

A solid mixture of the reagents $\left[\mathrm{Mo}_{2}\left(\mathrm{O}_{2} \mathrm{CCF}_{3}\right)_{4}\right](515 \mathrm{mg}, 0.80 \mathrm{mmol})$ and $\mathrm{Li}\left(2-(\mathrm{NDipp})-6-(\mathrm{Dipp}) \mathrm{C}_{5} \mathrm{H}_{3} \mathrm{~N}\right)$ (340 $\mathrm{mg}, 0.80 \mathrm{mmol}$ ) placed in a Young ampoule were prepared in the dry box. The reaction flask was cooled to $-20^{\circ} \mathrm{C}$ and $15 \mathrm{~mL}$ of diethyl ether was added. The reaction mixture was stirred for 12 hours and was allowed to reach room temperature. The desired product precipitated partially as a yellow solid and the solution was transferred to a Schlenk tube, concentrated, and stored at $-23{ }^{\circ} \mathrm{C}$ to obtain a crystalline fraction of complex 1c suitable for X-ray analysis, which was collected by filtration and dried under vacuum in a total yield of $70 \%$ (260 mg). Anal. Calcd. for $\mathrm{C}_{35} \mathrm{H}_{37} \mathrm{~F}_{9} \mathrm{Mo}_{2} \mathrm{~N}_{2} \mathrm{O}_{6}: \mathrm{C}, 44.51 ; \mathrm{H}, 3.95 ; \mathrm{N}, 2.97$. Found: C, 44.9; $\mathrm{H}, 3.4 ; \mathrm{N}, 2.5 .{ }^{1} \mathbf{H}$ NMR $\left(400 \mathrm{MHz}, \mathrm{C}_{6} \mathrm{D}_{6}, 25{ }^{\circ} \mathrm{C}\right): \delta=0.86\left(\mathrm{~d}, 6 \mathrm{H},{ }^{3} J_{\mathrm{HH}}=6.7 \mathrm{~Hz}, 2 \mathrm{Me}_{\mathrm{Dipp}}\right), 1.07,1.32(\mathrm{~d}$, $6 \mathrm{H}$ each, $\left.{ }^{3} J_{\mathrm{HH}}=6.8 \mathrm{~Hz}, 2 \mathrm{Me}_{\text {Dipp }}\right), 1.40\left(\mathrm{~d}, 6 \mathrm{H},{ }^{3} J_{\mathrm{HH}}=6.7 \mathrm{~Hz}, 2 \mathrm{Me}_{\text {Dipp }}\right), 2.51\left(\mathrm{sept}, 2 \mathrm{H},{ }^{3} J_{\mathrm{HH}}=6.7 \mathrm{~Hz}, 2\right.$ $\left.\mathrm{CHMe}_{2(\mathrm{Dipp})}\right), 2.77$ (sept, 2H, $\left.{ }^{3} J_{\mathrm{HH}}=6.7 \mathrm{~Hz}, 2 \mathrm{CHMe} \mathrm{M}_{\text {(Dipp') })}\right), 6.30\left(\mathrm{~d}, 1 \mathrm{H},{ }^{3} J_{\mathrm{HH}}=6.8 \mathrm{~Hz}, 5-\mathrm{py}\right), 6.50(\mathrm{dd}, 1 \mathrm{H}$, ${ }^{3} J_{\mathrm{HH}}=9.1 \mathrm{~Hz}, 3$-py), 6.77 (m, 3H, m-Dipp and p-Dipp), $6.83\left(\mathrm{dd}, 1 \mathrm{H},{ }^{3} J_{\mathrm{HH}}=9.1 \mathrm{~Hz},{ }^{3} J_{\mathrm{HH}}=6.8 \mathrm{~Hz}, 4\right.$-py), 7.10 (m, 3H, m-Dipp' and p-Dipp') ppm. ${ }^{13} \mathbf{C}\left\{{ }^{1} \mathbf{H}\right\}$ NMR (100 MHz, $\left.\mathrm{C}_{6} \mathrm{D}_{6}, 25{ }^{\circ} \mathrm{C}\right): \delta=21.5\left(\mathrm{Me}_{\text {Dipp}}\right), 24.8$, 25.8 ( Me $\left._{\text {Dipp') }}\right), 27.5$ (Me Dipp $), 28.3$ (CHMe 2 (Dipp')), 31.2 (CHMe 2 (Dipp)), 110.8 (5-py), 112.4 (3-py), 123.3 (mDipp), 125.2 (m-Dipp'), 128.1, 131.0 (p-Dipp and p-Dipp'), 132.7 (ipso-Dipp), 134.1 (4-py), 140,7 (ipsoDipp'), 146.1, 147.6 (o-Dipp' and o-Dipp), 152.9 (6-py), 169.0 (2-py) ppm. ${ }^{19} \mathbf{F}\left\{{ }^{1} \mathbf{H}\right\}$ NMR (376.5 MHz, $\left.\mathrm{C}_{6} \mathrm{D}_{6}, 25{ }^{\circ} \mathrm{C}\right): \delta-72.9\left(3 \mathrm{~F},\left(\mathrm{O}_{2} \mathrm{CCF}_{3}\right)_{\text {trans }}\right),-72.6\left(6 \mathrm{~F}, \mathrm{O}_{2} \mathrm{CCF}_{3}\right)$ ppm. ${ }^{1} \mathrm{H}$ and ${ }^{13} \mathrm{C}$ signals of the aryl ring with is referred to the ring directly bonded to the nitrogen atom. IR (nujol): $v_{a s}(\mathrm{OCO}) 1600, v(\mathrm{C}-\mathrm{F}) 1190, v_{\mathrm{d}}$ $\left(\mathrm{CF}_{3}\right) 730 \mathrm{~cm}^{-1}$.

\subsubsection{Synthesis of $\left[\mathrm{Mo}_{2}\left(\mu-\mathrm{O}_{2} \mathrm{CCF}_{3}\right)_{2}\left\{\mu-2-(\mathrm{NDipp})-6-(\mathrm{Xyl}) \mathrm{C}_{5} \mathrm{H}_{3} \mathrm{~N}_{2}\right]\right.$ (2b) and $\left[\mathrm{Mo}_{2}\left(\mu-\mathrm{O}_{2} \mathrm{CCF}_{3}\right)_{2}\{\mu-2-\right.$} (NDipp)-6-(Dipp) $\left.\mathrm{C}_{5} \mathrm{H}_{3} \mathrm{~N}_{2}\right]$ (2c).

Solid samples of $\left[\mathrm{Mo}_{2}\left(\mathrm{O}_{2} \mathrm{CCF}_{3}\right)_{4}\right](255 \mathrm{mg}, 0.40 \mathrm{mmol})$ and two equivalents of the corresponding LiAp' (321 mg for $\mathbf{2 b}$ and $334 \mathrm{mg}$ for $\mathbf{2 c}$ ) were mixed in a glovebox. The reaction flask was then cooled to $-20{ }^{\circ} \mathrm{C}$ and diethylther $(15 \mathrm{~mL})$ was added. The resulting suspension was stirred for 12 hours, while reaching slowly the room temperature. In both cases, the desired product precipitated partially as a yellow solid. The solution was transferred to a Schlenk tube and was kept in a refrigerator at $-23{ }^{\circ} \mathrm{C}$ for 24 hours. Yellow crystals of $\mathbf{2 b}$ 
and 2c suitable for X-ray diffraction separated out and were collected by filtration and dried under vacuum making total yields of 55\% (230 mg) and 60\% (300 mg), respectively. Two isomers of complex 2c were obtained in ratios that vary between $c a .2: 3$ and 3:2 from one preparation to another. Their separation was not achieved. 2b. Anal. Calcd. for $\mathrm{C}_{54} \mathrm{H}_{58} \mathrm{~F}_{6} \mathrm{Mo}_{2} \mathrm{~N}_{4} \mathrm{O}_{4}$ : C, 57.25; H, 5.16; N, 4.95. Found: C, 57.3; H, 5.6; N, 4.6. ${ }^{1} \mathrm{H}$ NMR $\left(500 \mathrm{MHz}, \mathrm{C}_{6} \mathrm{D}_{6}, 25{ }^{\circ} \mathrm{C}\right): \delta=1.16,1.41$ (d, $\left.12 \mathrm{H} \mathrm{each},{ }^{3} J_{\mathrm{HH}}=6.7 \mathrm{~Hz}, 4 \mathrm{Me}_{\text {Dipp}}\right), 2.02(\mathrm{~s}, 12 \mathrm{H}$, $\left.4 \mathrm{Me}_{\mathrm{Xyl}}\right), 2.93\left(\mathrm{sept}, 4 \mathrm{H},{ }^{3} \mathrm{~J}_{\mathrm{HH}}=6.7 \mathrm{~Hz}, 4 \mathrm{CHMe}\right), 5.83\left(\mathrm{dd}, 2 \mathrm{H},{ }^{3} J_{\mathrm{HH}}=6.7 \mathrm{~Hz},{ }^{4} J_{\mathrm{HH}}=0.8 \mathrm{~Hz}, 5-\mathrm{py}\right), 6.13(\mathrm{t}$, $\left.2 \mathrm{H},{ }^{3} J_{\mathrm{HH}}=7.6 \mathrm{~Hz}, p-\mathrm{Xyl}\right), 6.31\left(\mathrm{dd}, 2 \mathrm{H},{ }^{3} J_{\mathrm{HH}}=9.1 \mathrm{~Hz},{ }^{4} J_{\mathrm{HH}}=0.8 \mathrm{~Hz}, 3-\mathrm{py}\right), 6.39\left(\mathrm{~d}, 4 \mathrm{H},{ }^{3} J_{\mathrm{HH}}=7.6 \mathrm{~Hz}, m-\right.$ $\mathrm{Xyl}), 6.80\left(\mathrm{dd}, 2 \mathrm{H},{ }^{3} J_{\mathrm{HH}}=9.1 \mathrm{~Hz},{ }^{3} J_{\mathrm{HH}}=6.7 \mathrm{~Hz}, 4-\mathrm{py}\right), 7.16-7.19$ (m, 6H, m-Dipp and p-Dipp) ppm. ${ }^{13} \mathbf{C}\left\{{ }^{1} \mathbf{H}\right\}$ NMR $\left(125 \mathrm{MHz}, \mathrm{C}_{6} \mathrm{D}_{6}, 25^{\circ} \mathrm{C}\right): \delta=20.0\left(\mathrm{Me}_{\mathrm{Xyl}}\right), 24.3,25.9\left(\mathrm{Me}_{\text {Dipp }}\right), 27.90\left(\mathrm{CHMe}_{2}\right), 106.9(5-\mathrm{py})$, 111.3 (3-py), 124.5 (m-Dipp), 126.4 (p-Dipp), 127.8 (m-Xyl), 128.2 (p-Xyl), 134.7 (4-py), 135.6 (ipso-Xyl), 136.1 (o-Xyl), 141.2 (ipso-Dipp), 146.0 (o-Dipp), 166.7 (6-py and 2-py) ppm. ${ }^{19} \mathbf{F}\left\{{ }^{1} \mathbf{H}\right\}$ NMR (376.5 MHz, $\left.\mathrm{C}_{6} \mathrm{D}_{6}, 25^{\circ} \mathrm{C}\right): \delta=-71.7\left(6 \mathrm{~F}, \mathrm{O}_{2} \mathrm{CCF}_{3}\right) \mathrm{ppm}$. IR (nujol): $v_{\text {as }}(\mathrm{OCO}) 1605, v_{\mathrm{d}}\left(\mathrm{CF}_{3}\right) 730 \mathrm{~cm}^{-1}$. UV-visible (THF solution $10^{-4} \mathrm{M}$ ): $\lambda=485 \mathrm{~nm}$ with $\varepsilon=1800 \mathrm{~mol}^{-1} \mathrm{~L} \mathrm{~cm}^{-1}$. 2c (mixture of isomers A and B). Anal. Calcd. for $\mathrm{C}_{62} \mathrm{H}_{74} \mathrm{~F}_{6} \mathrm{Mo}_{2} \mathrm{~N}_{4} \mathrm{O}_{4}$ : C, 59.81; H, 5.99; N, 4.50. Found: C, 59.5; H, 5.4; N, 4.3. ${ }^{1} \mathbf{H}$ NMR (400 $\left.\mathrm{MHz}, \mathrm{C}_{6} \mathrm{D}_{6}, 25^{\circ} \mathrm{C}\right): \delta=0.93,\left(\mathrm{~d}, 12 \mathrm{H},{ }^{3} J_{\mathrm{HH}}=6.8 \mathrm{~Hz}, 4 \mathrm{Me}_{\mathrm{Dipp}}{ }^{\mathrm{B}}\right), 0.99,1.02\left(\mathrm{~d}, 12 \mathrm{H}\right.$ each, ${ }^{3} J_{\mathrm{HH}}=6.8 \mathrm{~Hz}, 4$ $\left.\mathrm{Me}_{\text {Dipp }}{ }^{\mathrm{A}}\right), 1.10,\left(\mathrm{~d}, 12 \mathrm{H},{ }^{3} J_{\mathrm{HH}}=6.8 \mathrm{~Hz}, 4 \mathrm{Me}_{\text {Dipp }}{ }^{\mathrm{B}}\right), 1.13,\left(\mathrm{~d}, 12 \mathrm{H},{ }^{3} J_{\mathrm{HH}}=6.8 \mathrm{~Hz}, 4 \mathrm{Me}_{\text {Dipp }}{ }^{\mathrm{A}}\right), 1.17(\mathrm{~d}, 12 \mathrm{H}$, $\left.{ }^{3} J_{\mathrm{HH}}=6.8 \mathrm{~Hz}, 4 \mathrm{Me}_{\text {Dipp }}{ }^{\mathrm{B}}\right), 1.26,\left(\mathrm{~d}, 12 \mathrm{H},{ }^{3} J_{\mathrm{HH}}=6.8 \mathrm{~Hz}, 4 \mathrm{Me}_{\text {Dipp }}{ }^{\mathrm{A}}\right), 1.29,\left(\mathrm{~d}, 12 \mathrm{H},{ }^{3} J_{\mathrm{HH}}=6.8 \mathrm{~Hz}, 4 \mathrm{Me}_{\text {Dipp }}{ }^{\mathrm{B}}\right)$, 2.65, 2.75, 2.96, 3.19 (sept, $4 \mathrm{H}$ each, ${ }^{3} J_{\mathrm{HH}}=6.8 \mathrm{~Hz}, 4 \mathrm{CHMe}_{2}{ }^{\mathrm{A}}, 4 \mathrm{CHMe}_{2}{ }^{\mathrm{B}}, 4 \mathrm{CHMe}_{2}{ }^{\mathrm{B}}$ and $\left.4 \mathrm{CHMe}_{2}{ }^{\mathrm{A}}\right), 6.01$, 6.12 (br. d, $2 \mathrm{H}$ each, ${ }^{3} J_{\mathrm{HH}}=6.7 \mathrm{~Hz}, 5-\mathrm{py}^{\mathrm{B}}$ and 5-py ${ }^{\mathrm{A}}$ ), 6.39, 6.45 (br. d, $2 \mathrm{H}$ each, ${ }^{3} J_{\mathrm{HH}}=9.0 \mathrm{~Hz}, 3-$ py $^{\mathrm{B}}$ and 3$\left.\mathrm{py}^{\mathrm{A}}\right), 6.62-6.70\left(\mathrm{~m}, 8 \mathrm{H}, m-\operatorname{Dipp}^{\mathrm{B}}, 4-\mathrm{py}^{\mathrm{A}}\right.$ and 4-py $\left.{ }^{\mathrm{B}}\right), 6.72-6.78\left(\mathrm{~m}, 6 \mathrm{H}, p-\operatorname{Dipp}^{\mathrm{B}}\right.$ and $\left.m-\operatorname{Dipp}^{\mathrm{A}}\right), 6.98(\mathrm{~m}, 2 \mathrm{H}$,

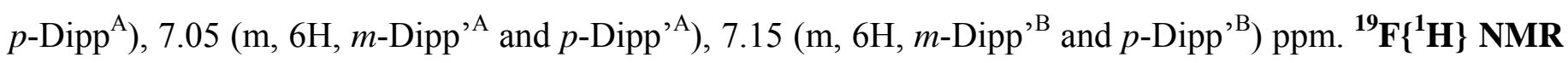
$\left(376.5 \mathrm{MHz}, \mathrm{C}_{6} \mathrm{D}_{6}, 25^{\circ} \mathrm{C}\right): \delta=-70.9,-72.6\left(6 \mathrm{~F}, \mathrm{O}_{2} \mathrm{CCF}_{3}\right.$, isomers $\mathrm{A}$ and $\left.\mathrm{B}\right) \mathrm{ppm}$.

\subsection{Preparation of bis-acetate bis-aminopyridinate dimolybdenum complexes 3.}

\subsubsection{Synthesis of $\left[\mathrm{Mo}_{2}\left(\mu-\mathrm{O}_{2} \mathrm{CMe}\right)_{2}\left\{\mu-2-(\mathrm{NXyl})-6-(\mathrm{Xyl}) \mathrm{C}_{5} \mathrm{H}_{3} \mathrm{~N}\right\}_{2}\right]$, (3a).}

$\left[\mathrm{Mo}_{2}\left(\mathrm{O}_{2} \mathrm{CMe}\right)_{4}\right](0.55 \mathrm{~g}, 1.29 \mathrm{mmol})$ and $\left.\left\{\mathrm{Li}(2-\mathrm{NXyl})-6-(\mathrm{Xyl}) \mathrm{C}_{5} \mathrm{H}_{3} \mathrm{~N}\right)\right\}(1.0 \mathrm{~g}, 2.58 \mathrm{mmol})$ were placed in an ampoule and dissolved in diethyl ether $(15 \mathrm{~mL})$ at $-40{ }^{\circ} \mathrm{C}$. The resulting suspension was stirred for 12 hours allowing to reach slowly the room temperature. The solution was filtered and the solid was washed several times with diethyl ether to give 3a as a yellow-brown solid in a ca. 90\% (1.1 g) yield. Crystals suitable for X-ray analysis were obtained by cooling down a hot saturated solution of complex 3a in THF. Anal. Calcd. for $\mathrm{C}_{46} \mathrm{H}_{48} \mathrm{Mo}_{2} \mathrm{~N}_{4} \mathrm{O}_{4}$ : C, 60.53; H, 5.30; N, 6.14. Found: C, 60.7; H, 5.7; N, 5.7. ${ }^{1} \mathbf{H}$ NMR (500 $\left.\mathrm{MHz}, \mathrm{C}_{6} \mathrm{D}_{6}, 25^{\circ} \mathrm{C}\right): \delta=2.13,\left(\mathrm{~s}, 12 \mathrm{H}, 4 \mathrm{Me}_{\mathrm{Xyl}}{ }^{\prime}\right), 2.14\left(\mathrm{~s}, 12 \mathrm{H}, 4 \mathrm{Me}_{\mathrm{Xyl}}\right), 2.25\left(\mathrm{~s}, 6 \mathrm{H}, \mathrm{Me}_{\mathrm{OAc}}\right), 5.96(\mathrm{dd}, 2 \mathrm{H}$, $\left.{ }^{3} J_{\mathrm{HH}}=6.5 \mathrm{~Hz},{ }^{4} J_{\mathrm{HH}}=0.9 \mathrm{~Hz}, 5-\mathrm{py}\right), 6.28-6.32\left(\mathrm{~m}, 4 \mathrm{H}, 3\right.$-py and $p$-Xyl'), $6.43\left(\mathrm{~d}, 4 \mathrm{H},{ }^{3} J_{\mathrm{HH}}=7.6 \mathrm{~Hz}, m-\right.$ Xyl'), $6.89\left(\mathrm{dd}, 2 \mathrm{H},{ }^{3} J_{\mathrm{HH}}=8.7 \mathrm{~Hz},{ }^{3} J_{\mathrm{HH}}=6.5 \mathrm{~Hz}, 4-\mathrm{py}\right), 6.99-7.06\left(\mathrm{~m}, 6 \mathrm{H}, \mathrm{AB}_{2}\right.$ system, $m-\mathrm{Xyl}$ and $p$-Xyl) ppm. ${ }^{13} \mathrm{C}\left\{{ }^{1} \mathbf{H}\right\}$ NMR (125 MHz, $\left.\mathrm{C}_{6} \mathrm{D}_{6}, 25{ }^{\circ} \mathrm{C}\right): \delta=18.6\left(\mathrm{Me}_{\mathrm{Xyl}}\right), 20.2\left(\mathrm{Me}_{\mathrm{Xyl}}\right), 22.5\left(\mathrm{Me}_{\mathrm{OAc}}\right), 105.1$ (5-py), 
108.2 (3-py), 124.1 (p-Xyl), 126.5 (m-Xyl'), 128.0 (p-Xyl'), 128.2 (m-Xyl), 134.1 (4-py), 134.9 (o-Xyl'), 136.0 (o-Xyl), 136.3 (ipso-Xyl), 144.7 (ipso-Xyl'), 154.5 (6-py), 164.0 (2-py), $177.7\left(\mathrm{O}_{2} C \mathrm{Me}\right) \mathrm{ppm}$. UV-visible (THF solution $10^{-4} \mathrm{M}$ ): $\lambda=420$ and $500 \mathrm{~nm}$ with $\varepsilon=9000,2800 \mathrm{~mol}^{-1} \mathrm{~L} \mathrm{~cm}^{-1}$, respectively. ${ }^{1} \mathrm{H}$ and ${ }^{13} \mathrm{C}$ signals of the aryl ring with' is referred to the ring directly bonded to the nitrogen atom.

\subsubsection{Synthesis of $\left[\mathrm{Mo}_{2}\left(\mu-\mathrm{O}_{2} \mathrm{CMe}\right)_{2}\left\{\mu-2-(\mathrm{NDipp})-6-(\mathrm{Xyl}) \mathrm{C}_{5} \mathrm{H}_{3} \mathrm{~N}\right\}_{2}\right]$, (3b).}

To a solid mixture of $\left[\mathrm{Mo}_{2}\left(\mathrm{O}_{2} \mathrm{CMe}\right)_{4}\right](428 \mathrm{mg}, 1.0 \mathrm{mmol})$ and $\left.\left\{\mathrm{Li}(2-\mathrm{NDipp})-6-(\mathrm{Xyl}) \mathrm{C}_{5} \mathrm{H}_{3} \mathrm{~N}\right)\right\}_{2}\left(\mathrm{OEt}_{2}\right)$ (803 mg, $1.0 \mathrm{mmol}$ ) placed in a Young ampoule were added $25 \mathrm{~mL}$ of diethyl ether previously cooled to -30 ${ }^{\circ} \mathrm{C}$. The reaction mixture was stirred for 24 hours allowing to reach slowly the room temperature. The solvent was removed under vacuum and the solid residue was extracted with $35 \mathrm{~mL}$ of hexane. The resulting brown-orange suspension was centrifuged, the clear solution transferred to a Schlenk tube and the solvent removed under vacuum until the solid was totally dried. Then, $25 \mathrm{~mL}$ of hexane were added and the orangeyellow solution was concentrated to $c a .12 \mathrm{~mL}$, and stored in the refrigerator at $-23{ }^{\circ} \mathrm{C}$ during two days. Orange crystals suitable for X-ray diffraction were isolated by filtration, and dried under vacuum for 2 hours in a ca. $80 \%$ yield $(800 \mathrm{mg})$. Anal. Calcd. for $\mathrm{C}_{54} \mathrm{H}_{64} \mathrm{Mo}_{2} \mathrm{~N}_{4} \mathrm{O}_{4}$ : C, 63.28; H, 6.29; N, 5.47. Found: C, 62.9; $\mathrm{H}, 6.5 ; \mathrm{N}, 5.9 .{ }^{1} \mathbf{H}$ NMR $\left(500 \mathrm{MHz}, \mathrm{C}_{6} \mathrm{D}_{6}, 25{ }^{\circ} \mathrm{C}\right): \delta=1.16,1.21\left(\mathrm{~d}, 12 \mathrm{H}\right.$ each, $\left.{ }^{3} J_{\mathrm{HH}}=6.9 \mathrm{~Hz}, 8 \mathrm{Me}_{\text {Dipp }}\right)$, $2.06\left(\mathrm{~s}, 12 \mathrm{H}, 4 \mathrm{Me}_{\mathrm{Xyl}}\right), 2.42\left(\mathrm{~s}, 6 \mathrm{H}, \mathrm{Me}_{\mathrm{OAc}}\right), 3.38\left(\mathrm{sept}, 4 \mathrm{H},{ }^{3} J_{\mathrm{HH}}=6.9 \mathrm{~Hz}, 4 \mathrm{CHMe}\right.$ ), $5.61\left(\mathrm{dd}, 2 \mathrm{H},{ }^{3} J_{\mathrm{HH}}=\right.$ $\left.6.9 \mathrm{~Hz},{ }^{4} J_{\mathrm{HH}}=1.2 \mathrm{~Hz}, 5-\mathrm{py}\right), 6.29\left(\mathrm{dd}, 2 \mathrm{H},{ }^{3} J_{\mathrm{HH}}=8.9 \mathrm{~Hz},{ }^{4} J_{\mathrm{HH}}=1.2 \mathrm{~Hz}, 3-\mathrm{py}\right), 6.60\left(\mathrm{~d}, 4 \mathrm{H},{ }^{3} J_{\mathrm{HH}}=7.6 \mathrm{~Hz}\right.$, $m$-Xyl), $6.71\left(\mathrm{dd}, 2 \mathrm{H},{ }^{3} J_{\mathrm{HH}}=8.9 \mathrm{~Hz},{ }^{3} J_{\mathrm{HH}}=6.9 \mathrm{~Hz}, 4-\mathrm{py}\right), 6.79\left(\mathrm{t}, 2 \mathrm{H},{ }^{3} J_{\mathrm{HH}}=7.6 \mathrm{~Hz}, p-\mathrm{Xyl}\right), 7.08(\mathrm{~s}, 6 \mathrm{H}$, $\mathrm{AB}_{2}$ system, $m$-Dipp and $p$-Dipp) ppm. ${ }^{13} \mathbf{C}\left\{{ }^{1} \mathbf{H}\right\}$ NMR $\left(125 \mathrm{MHz}, \mathrm{C}_{6} \mathrm{D}_{6}, 25{ }^{\circ} \mathrm{C}\right): \delta=19.4\left(\mathrm{Me}_{\mathrm{Xyl}}\right), 22.6$ ( $\mathrm{Me}_{\mathrm{OAc}}$ ), 25.2, 25.3 (Me $\mathrm{Mipp}_{\text {p) }} 27.51$ (CHMe 2$), 107.4$ (5-py), 110.8 (3-py), 124.5 (m-Dipp), 126.1 (p-Dipp), 127.6 (m-Xyl), 129.0 (p-Xyl), 133.4 (4-py), 136.0 (o-Xyl), 137.7 (ipso-Xyl), 142.5 (ipso-Dipp), 145.8 (oDipp), 157.3 (6-py), 167.6 (2-py), $178.6\left(\mathrm{O}_{2} \mathrm{CMe}\right) \mathrm{ppm}$. UV-visible (diethyl ether solution $\left.10^{-4} \mathrm{M}\right): \lambda=250$ and $335 \mathrm{~nm}$ (strong); 380, 440 and $500 \mathrm{~nm}$ with $\varepsilon=5300,6200,1800 \mathrm{~mol}^{-1} \mathrm{~L} \mathrm{~cm}^{-1}$, respectively.

\subsubsection{Synthesis of $\left[\mathrm{Mo}_{2}\left(\mu-\mathrm{O}_{2} \mathrm{CMe}\right)_{2}\left\{\mu-2-(\mathrm{NDipp})-6-(\mathrm{Xyl}) \mathrm{C}_{5} \mathrm{H}_{3} \mathrm{~N}\right\}_{2}\right]$, (3c).}

$\left[\mathrm{Mo}_{2}(\mathrm{OAc})_{4}\right](0.43 \mathrm{~g}, 1 \mathrm{mmol})$ and $\left.\left\{\mathrm{Li}(2-\mathrm{NDipp})-6-(\mathrm{Dipp}) \mathrm{C}_{5} \mathrm{H}_{3} \mathrm{~N}\right)\right\} \quad(1.14 \mathrm{~g}, 2 \mathrm{mmol})$ were placed together in a ampoule. Toluene $(15 \mathrm{~mL})$ was added and the resulting suspension was stirred for 12 hours at room temperature. An orange-red solid precipitated and the solution was filtered. The solid was washed several time with THF at room temperature and dried under vacuum to give an orange solid in a $c a$. $75 \%$ yield $(0.85 \mathrm{~g})$. Crystallization was afforded by cooling down a hot saturated solution of complex $3 \mathrm{c}$ in toluene. Anal. Calcd. for $\mathrm{C}_{62} \mathrm{H}_{80} \mathrm{Mo}_{2} \mathrm{~N}_{4} \mathrm{O}_{4}$ : C, 65.48; H, 7.09; N, 4.93. Found: C, 65.7; H, 7.3; N, 4.9. ${ }^{1} \mathbf{H}$ NMR $\left(400 \mathrm{MHz}, \mathrm{C}_{6} \mathrm{D}_{6}, 25{ }^{\circ} \mathrm{C}\right): \delta=1.00\left(\mathrm{~d}, 12 \mathrm{H},{ }^{3} J_{\mathrm{HH}}=6.7 \mathrm{~Hz}, 4 \mathrm{Me}_{\mathrm{Dipp}}\right), 1.12,1.21\left(\mathrm{~d}, 12 \mathrm{H}\right.$ each, ${ }^{3} J_{\mathrm{HH}}=$ $\left.6.9 \mathrm{~Hz}, 4 \mathrm{Me}_{\text {Dipp }}\right), 1.31\left(\mathrm{~d}, 12 \mathrm{H},{ }^{3} J_{\mathrm{HH}}=6.9 \mathrm{~Hz}, 4 \mathrm{Me}_{\mathrm{Dipp}}\right), 2.41,\left(\mathrm{~s}, 6 \mathrm{H}, \mathrm{Me}_{\mathrm{OAc}}\right), 2.83\left(\mathrm{sept}, 4 \mathrm{H},{ }^{3} J_{\mathrm{HH}}=6.7 \mathrm{~Hz}\right.$, 
$\left.\left.4 \mathrm{CHMe}_{2}\right)^{\prime}\right), 3.00\left(\mathrm{sept}, 4 \mathrm{H},{ }^{3} J_{\mathrm{HH}}=6.7 \mathrm{~Hz}, 4 \mathrm{CHMe}_{2}\right.$ ), 6.08 (br. d, 2H, $\left.{ }^{3} J_{\mathrm{HH}}=6.2 \mathrm{~Hz}, 5-\mathrm{py}\right), 6.26$ (br. d, 2H, $\left.{ }^{3} J_{\mathrm{HH}}=8.7 \mathrm{~Hz}, 3-\mathrm{py}\right), 6.72$ (m, 6H, m-Dipp and 4-py), 6.81 (m, 2H, p-Dipp), 7.18 (m, 6H, m-Dipp' and pDipp') ppm. ${ }^{13} \mathbf{C}\left\{{ }^{1} \mathbf{H}\right\}$ NMR (100 MHz, $\left.\mathrm{C}_{6} \mathrm{D}_{6}, 25{ }^{\circ} \mathrm{C}\right): \delta=22.4\left(\mathrm{Me}_{\text {Dipp }}\right), 22.7\left(\mathrm{Me}_{\mathrm{OAc}}\right), 24.9,25.1\left(\mathrm{Me}_{\text {Dipp }}\right)$, 26.9 ( Me $\left._{\text {Dipp }}\right), 27.8$ ( $\left.\mathrm{CHMe}_{2}\right), 30.5$ (CHMe $\left.{ }_{2}\right), 108.6$ (5-py), 110.6 (3-py), 122.5 (m-Dipp), 124.5 (m-Dipp'), 126.3 (p-Dipp'), 129.6 (p-Dipp), 131.9 (4-py), 134.5 (ipso-Dipp), 145.1 (o-Dipp), 146.4 (o-Dipp'), 153.7 (6py), 167.4 (2-py), $179.2\left(\mathrm{O}_{2} \mathrm{CMe}\right)$ ppm. UV-visible (THF solution $\left.10^{-5} \mathrm{M}\right): \lambda=320,350,420$ and $505 \mathrm{~nm}$ with $\varepsilon=41170,23350,14600,3600 \mathrm{~mol}^{-1} \mathrm{~L} \mathrm{~cm}^{-1}$, respectively. ${ }^{1} \mathrm{H}$ and ${ }^{13} \mathrm{C}$ signals of the aryl ring with' is referred to the ring directly bonded to the nitrogen atom.

\subsection{Preparation of the mono-amidinate dimolybdenum, bis-aminopyridinate ditungsten and bis-amidinate ditungsten complexes 4-6.}

3.4.1 Synthesis of $\left[W_{2}\left(\mu-O_{2} C C F_{3}\right)_{2}\left\{\mu-2-(N D i p p)-6-(X y l) C_{5} H_{3} N\right\}_{2}\right],(4 b)$.

A solid mixture of the reagents $\left[\mathrm{W}_{2}\left(\mathrm{O}_{2} \mathrm{CCF}_{3}\right)_{4}\right](410 \mathrm{mg}, 0.5 \mathrm{mmol})$ and $\{\mathrm{Li}(2-\mathrm{NDipp})-6-$ $\left.\left.(\mathrm{Xyl}) \mathrm{C}_{5} \mathrm{H}_{3} \mathrm{~N}\right)\right\}_{2}\left(\mathrm{OEt}_{2}\right)(402 \mathrm{mg}, 0.5 \mathrm{mmol})$ placed in a Young ampoule was prepared in the dry box. The reaction flask was cooled to $-20^{\circ} \mathrm{C}$ and $35 \mathrm{~mL}$ of diethyl ether was added. The reaction mixture was stirred for 24 hours while allowing to reach room temperature. The solvent was removed under vacuum and the solid residue was extracted with $30 \mathrm{~mL}$ of hexane. The resulting brown-yellow suspension was centrifuged and the clear solution transferred to a Schlenk tube, concentrated, and stored in the refrigerator at $-23{ }^{\circ} \mathrm{C}$ during 24 hours. A yellow solid was isolated by filtration and dried under vacuum for 2 hours in a ca. 54\% yield (382 mg). Anal. Calcd. for $\mathrm{C}_{54} \mathrm{H}_{58} \mathrm{~F}_{6} \mathrm{~N}_{4} \mathrm{O}_{4} \mathrm{~W}_{2}$ : C, 49.56; H, 4.47; N, 4.28. Found: C, 49.5; H, 4.6; N, 3.9. ${ }^{1} \mathbf{H}$ NMR $\left(500 \mathrm{MHz}, \mathrm{C}_{6} \mathrm{D}_{6}, 25{ }^{\circ} \mathrm{C}\right): \delta=1.10,1.31$ (d, $12 \mathrm{H}$ each, $\left.{ }^{3} J_{\mathrm{HH}}=6.8 \mathrm{~Hz}, 4 \mathrm{Me}_{\text {Dipp }}\right), 2.02(\mathrm{~s}, 6 \mathrm{H}$, MeXyl), 3.06 (sept, $\left.4 \mathrm{H},{ }^{3} J_{\mathrm{HH}}=6.8 \mathrm{~Hz}, 4 \mathrm{CHMe}_{2}\right), 5.58\left(\mathrm{dd}, 2 \mathrm{H},{ }^{3} J_{\mathrm{HH}}=6.7 \mathrm{~Hz},{ }^{4} J_{\mathrm{HH}}=1.3 \mathrm{~Hz}, 5-\mathrm{py}\right), 6.31$ $\left(\mathrm{dd}, 2 \mathrm{H},{ }^{3} J_{\mathrm{HH}}=9.0 \mathrm{~Hz},{ }^{4} J_{\mathrm{HH}}=1.3 \mathrm{~Hz}, 3-\mathrm{py}\right), 6.44\left(\mathrm{dd}, 2 \mathrm{H},{ }^{3} J_{\mathrm{HH}}=9.0 \mathrm{~Hz},{ }^{3} J_{\mathrm{HH}}=6.7 \mathrm{~Hz}, 4-\mathrm{py}\right), 6.55(\mathrm{~d}, 4 \mathrm{H}$, $\left.{ }^{3} J_{\mathrm{HH}}=7.5 \mathrm{~Hz}, m-\mathrm{Xyl}\right), 6.72\left(\mathrm{t}, 2 \mathrm{H},{ }^{3} J_{\mathrm{HH}}=7.5 \mathrm{~Hz}, p\right.$-Xyl), $7.16\left(\mathrm{~m}, 6 \mathrm{H}, m\right.$-Dipp and $p$-Dipp) ppm. ${ }^{13} \mathbf{C}\left\{{ }^{1} \mathbf{H}\right\}$ NMR (125 MHz, $\left.\mathrm{C}_{6} \mathrm{D}_{6}, 25^{\circ} \mathrm{C}\right): \delta=19.5$ ( $\left.\mathrm{Me}_{\mathrm{Xyl}}\right), 25.1,25.5$ (Me $\mathrm{Dipp}_{\text {) }}$ ), $28.0\left(\mathrm{CHMe}_{2}\right), 109.8$ (5-py), 113.1 (3py), 125.3 (m-Dipp), 127.4 (p-Dipp), 128.3 (m-Xyl), 130.4 (p-Xyl), 133.8 (4-py), 136.0 (ipso-Xyl), 136.5 (oXyl), 140.4 (ipso-Dipp), 146.8 (o-Dipp), 155.6, (6-py), 169.1 (2-py) ppm. ${ }^{19} \mathbf{F}\left\{{ }^{1} \mathbf{H}\right\}$ NMR (376.5 MHz, $\mathrm{C}_{6} \mathrm{D}_{6}$, $\left.25^{\circ} \mathrm{C}\right): \delta=-76.9\left(6 \mathrm{~F}, \mathrm{O}_{2} \mathrm{CCF}_{3}\right) \mathrm{ppm}$.

\subsubsection{Synthesis of $\left[\mathrm{Mo}_{2}\left(\mu-\mathrm{O}_{2} \mathrm{CCF}_{3}\right)_{3}\left\{\mu-\mathrm{HC}\left(\mathrm{N}-2,6-i \mathrm{Pr}_{2} \mathrm{C}_{6} \mathrm{H}_{3}\right)_{2}\right\}\right]$, (5).}

To a solid mixture of $\left[\mathrm{Mo}_{2}\left(\mathrm{O}_{2} \mathrm{CCF}_{3}\right)_{4}\right](645 \mathrm{mg}, 1.0 \mathrm{mmol})$ and $\mathrm{Li}\left\{\mathrm{HC}\left(\mathrm{N}-2,6-\mathrm{Pr}_{2} \mathrm{C}_{6} \mathrm{H}_{3}\right)_{2}\right\}(\mathrm{THF})_{2} \quad(515 \mathrm{mg}$, $1.0 \mathrm{mmol}$ ) placed in a Young ampoule were added $15 \mathrm{~mL}$ of THF previously cooled to $-20^{\circ} \mathrm{C}$. The reaction mixture was stirred for 24 hours allowing to reach slowly the room temperature. The desired product precipitated partially as a yellow solid. The solution was transferred to a Schlenk tube and stored in a refrigerator at $-23{ }^{\circ} \mathrm{C}$ for 24 hours to give yellow crystals of 5 suitable for X-ray analyses. Yield: $60 \%$ (253 
mg). Anal. Calcd. for $\mathrm{C}_{31} \mathrm{H}_{35} \mathrm{~F}_{9} \mathrm{Mo}_{2} \mathrm{~N}_{4} \mathrm{O}_{6}$ : C, 41.63; H, 3.94; N, 3.13. Found: C, 41.9; H, 4.4; N, 3.6. ${ }^{1} \mathbf{H}$ NMR (400 MHz, $\left.\mathrm{C}_{6} \mathrm{D}_{6}, 25{ }^{\circ} \mathrm{C}\right): \delta=1.22,1.25\left(\mathrm{~d}, 12 \mathrm{H}\right.$ each, ${ }^{3} J_{\mathrm{HH}}=6.8 \mathrm{~Hz}, 4 \mathrm{Me}_{\text {Dipp }}$ ), 3.36 (sept, $4 \mathrm{H},{ }^{3} J_{\mathrm{HH}}=$ 6.8 Hz, $\left.4 \mathrm{CHMe}_{2}\right), 6.99-7.08\left(\mathrm{~m}, 6 \mathrm{H}, \mathrm{AB}_{2}\right.$ system, $m$-Dipp and $p$-Dipp), $8.02(\mathrm{~s}, 1 \mathrm{H}, \mathrm{NC}(H) \mathrm{N}) \mathrm{ppm} .{ }^{13} \mathbf{C}\left\{{ }^{1} \mathbf{H}\right\}$ NMR $\left(100 \mathrm{MHz}, \mathrm{C}_{6} \mathrm{D}_{6}, 25^{\circ} \mathrm{C}\right): \delta=25.3,26.2$ (Me $\left.\mathrm{Mipp}_{\text {Dip }}\right), 28.1\left(\mathrm{CHMe}_{2}\right), 124.5$ ( $m$-Dipp), 127.0 (p-Dipp), 143.2 (ipso-Dipp), 146.1 (o-Dipp), $166.0(\mathrm{NC}(\mathrm{H}) \mathrm{N}) \mathrm{ppm} .{ }^{19} \mathbf{F}\left\{{ }^{1} \mathbf{H}\right\} \mathbf{N M R}\left(376.5 \mathrm{MHz}, \mathrm{C}_{6} \mathrm{D}_{6}, 25{ }^{\circ} \mathrm{C}\right): \delta=$ $\left.-72.7\left(6 \mathrm{~F}, \mathrm{O}_{2} \mathrm{CCF}_{3}\right),-72.0\left(3 \mathrm{~F}, \mathrm{O}_{2} \mathrm{CCF}_{3}\right)_{\text {trans }}\right)$ ppm. UV-visible (diethyl ether solution $\left.10^{-5} \mathrm{M}\right): \lambda=330,350$ and $430(\mathrm{sh}) \mathrm{nm}$ with $\varepsilon=2200,1800$ and $460 \mathrm{~mol}^{-1} \mathrm{~L} \mathrm{~cm}^{-1}$, respectively.

\subsubsection{Synthesis of $\left[\mathrm{W}_{2}\left(\mu-\mathrm{O}_{2} \mathrm{CCF}_{3}\right)_{2}\left\{\mu-\mathrm{HC}\left(\mathrm{N}-2,6-i \mathrm{Pr}_{2} \mathrm{C}_{6} \mathrm{H}_{3}\right)_{2}\right\}_{2}\right]$, (6).}

The reagents $\left[\mathrm{W}_{2}\left(\mathrm{O}_{2} \mathrm{CCF}_{3}\right)_{4}\right](820 \mathrm{mg}, 1.0 \mathrm{mmol})$ and $\mathrm{Li}\left\{\mathrm{HC}\left(\mathrm{N}-2,6-i \mathrm{Pr}_{2} \mathrm{C}_{6} \mathrm{H}_{3}\right)_{2}\right\}(\mathrm{THF})_{2}(1030 \mathrm{mg}, 2.0$ mmol) were mixed in the dry box, the reaction flask was then cooled to $-40{ }^{\circ} \mathrm{C}$ and $10 \mathrm{~mL}$ of $\mathrm{THF}$ was added, resulting in a dark orange solution after 2 hours of stirring. The mixture was allowed to reach room temperature with continuous stirring and was further reacted for $c a .12 \mathrm{~h}$, to give an orange-yellow solid that was washed with THF $(10 \mathrm{~mL})$ and with pentane $(10 \mathrm{~mL})$. The solid was dried under vacuum for 2 hours to obtain $900 \mathrm{mg}$ of the pure product (yield: 70\%). The product was crystallized by cooling down a hot saturated solution of complex 6 in toluene to yield yellow crystals suitable for X-ray diffraction. Anal. Calcd. for $\mathrm{C}_{54} \mathrm{H}_{70} \mathrm{~F}_{6} \mathrm{~N}_{4} \mathrm{O}_{4} \mathrm{~W}_{2}$ : C, 49.10; H, 5.34; N, 4.24. Found: C, 48.8; H, 5.7; N, 4.4. ${ }^{1} \mathbf{H}$ NMR (400 MHz, $\left.\mathrm{C}_{6} \mathrm{D}_{6}, 2{ }^{\circ} \mathrm{C}\right): \delta=1.17,1.31\left(\mathrm{~d}, 24 \mathrm{H}\right.$ each, $\left.{ }^{3} J_{\mathrm{HH}}=6.7 \mathrm{~Hz}, 4 \mathrm{CHMe} 2\right), 3.23\left(\mathrm{sept}, 8 \mathrm{H},{ }^{3} J_{\mathrm{HH}}=6.7 \mathrm{~Hz}, 8\right.$ $\left.\mathrm{CHMe}_{2}\right)$, 6.99-7.07 (m, 12H, AB 2 system, m-Dipp and p-Dipp), 8.04 (s, 2H, NC(H)N) ppm. ${ }^{13} \mathbf{C}\left\{{ }^{1} \mathbf{H}\right\}$ NMR $\left(100 \mathrm{MHz}, \mathrm{C}_{6} \mathrm{D}_{6}, 25{ }^{\circ} \mathrm{C}\right): \delta=25.1,25.9$ (Me $\left.{ }_{\text {Dipp }}\right), 27.8\left(\mathrm{CHMe}_{2}\right), 124.1$ (m-Dipp), 126.9 (p-Dipp), 142.1 (ipso-Dipp), 145.9 (o-Dipp), $165.6(\mathrm{NC}(\mathrm{H}) \mathrm{N}) \mathrm{ppm} .{ }^{19} \mathbf{F}\left\{{ }^{1} \mathbf{H}\right\} \mathbf{N M R}\left(376.5 \mathrm{MHz}, \mathrm{C}_{6} \mathrm{D}_{6}, 25{ }^{\circ} \mathrm{C}\right): \delta=-67.6(6 \mathrm{~F}$, $\mathrm{O}_{2} \mathrm{CCF}_{3}$ ) ppm. UV-visible (benzene solution $10^{-4} \mathrm{M}$ ): $\lambda=350,435$ and $460 \mathrm{~nm}, \varepsilon=11500$, 6600 and 7400 $\mathrm{mol}^{-1} \mathrm{~L} \mathrm{~cm}^{-1}$, respectively.

\section{Acknowledgments}

Financial support (FEDER contribution and Subprogramas Juan de la Cierva) from the Spanish Ministry of Science and Innovation (Projects CTQ2010-15833, CTQ2011-23862-C02-01 and Consolider-Ingenio 2010 CSD2007-00006), and the Junta de Andalucía (Grant FQM-119 and Project P09-FQM-5117) is gratefully acknowledged. 


\section{Appendix A. Supplementary material}

Crystallographic data for the structural analysis have been deposited with the Cambridge Crystallographic Data Centre, CCDC No. 995168-995176 (1b-c), (2b-c), (3a-c), (5), and (6). These data can be obtained free of charge via http://www.ccdc.cam.ac.uk/conts/retrieving.html, or from the Cambridge Crystallographic Data Centre, 12 Union Road, Cambridge CB2 1EZ, UK; fax: (+44) 1223-336-033; or email: deposit@ccdc.cam.ac.uk.

\section{References}

[1] T.A. Stephenson, E. Bannister, G. Wilkinson, J. Chem. Soc. (1964) 2538.

[2] F.A. Cotton, C.A. Murillo, R.A. Walton, Multiple Bonds Between Metal Atoms, Springer, Berlin, 3rd ed., 2005.

[3] A.P. Sattelberger, K.W. McLaughlin, J.C. Huffman, J. Am. Chem. Soc. 103 (1981) 2880.

[4] (a) F.A. Cotton, C. Lin, C.A. Murillo, Acc. Chem. Res. 34 (2001) 759; (b) F.A. Cotton, Z. Li, C.A. Murillo, Eur. J. Inorg. Chem. (2007) 3509.

[5] (a) M.H. Chisholm, N.J. Patmore, Acc. Chem. Res. 40 (2007) 19; (b) M.H. Chisholm, B.J. Lear, Chem. Soc. Rev. 40 (2011) 5254; (c) D.J. Brown, M.H. Chisholm, J.C. Gallucci, Dalton Trans. (2008) 1615.

[6] (a) L.A. Wilkinson, L. McNeill, A.J.H.M. Meijer, N.J. Patmore, J. Am. Chem. Soc. 135 (2013) 1723;

(b) L.A. Wilkinson, L. McNeill, P.A. Scattergood, N.J. Patmore, Inorg. Chem. 52 (2013) 9683.

[7] For a relevant catalytic application of bulky ligands see for instance: D.S. Surry, S.L. Buchwald, Chem. Sci. 2 (2011) 27.

[8] (a) T. Nguyen, A.D. Sutton, M. Brynda, J.C. Fettinger, G.J. Long, P.P. Power, Science 310 (2005) 844; (b) R. Wolf, C. Ni, T. Nguyen, M. Brynda, G.J. Long, A.D. Sutton, R.C. Fischer, J.C. Fettinger, M. Hellman, L. Pu, P.P. Power, Inorg. Chem. 46 (2007) 11277.

[9] (a) A. Noor, G. Glatz, R. Müller, M. Kaupp, S. Demeshko, R. Kempe, Nature Chem. 1 (2009) 322; (b) F.R. Wagner, A. Noor, R. Kempe, Nature Chem. 1 (2009) 529; (c) A. Noor, F.R. Wagner, R. Kempe, Angew. Chem. Int. Ed. 47 (2008) 7246; (d) A. Noor, T. Bauer, T.K. Todorova, B. Weber, L. Gagliardi, R. Kempe, Chem. Eur. J. 19 (2013) 9825.

[10] (a) Y.-C. Tsai, H.-Z. Chen, C.-C. Chang, J.-S.K. Yu, G.-H. Lee, Y. Wang, T.-S. Kuo, J. Am. Chem. Soc., 131 (2009) 12534; (b) Y.-C. Tsai, C.-W. Hsu, J.-S.K. Yu, G.-H. Lee, Y. Wang, T.-S. Kuo, Angew. Chem. Int. Ed. 47 (2008) 7250; (c) C.-W. Hsu, J.-S.K. Yu, C.-H. Yen, G.-H. Lee, Y. Wang, Y.-C. Tsai, Angew. Chem. Int. Ed. 47 (2008) 9933; (d) Y.-L. Huang, D.-Y. Lu, H.-C. Yu, J.-S.K. Yu, 
C.-W. Hsu, T.-S. Kuo, G.-H. Lee, Y. Wang, Y.-C. Tsai, Angew. Chem. Int. Ed. 51 (2012) 7781; (e) S.-C. Liu, W.-L. Ke, J.-S.K. Yu, T.-S. Kuo, Y.-C. Tsai, Angew. Chem. Int. Ed. 51 (2012) 6394.

[11] K.A. Kreisel, G.P.A. Yap, O. Dmitrenko, C.R. Landis, K.H. Theopold, J. Am. Chem. Soc. 129 (2007) 14162.

[12] A. Noor, G. Glatz, R. Müller, M. Kaupp, S. Demeshko, R. Kempe, Z. Anorg. Allg. Chem. 635 (2009) 1149.

[13] Y.-L. Huang, D.-Y. Lu, H.-C. Yu, J.-S.K. Yu, C.-W. Hsu, T.-S. Kuo, G.-H. Lee, Y. Wang, Y.-C. Tsai, Angew. Chem. Int. Ed. 51 (2012) 7781.

[14] (a) L.J. Clouston, R.B. Siedschlag, P.A. Rudd, N. Planas, S. Hu, A.D. Miller, L. Gagliardi, C.C. Lu, J. Am. Chem. Soc. 135 (2013) 13142; (b) P.A. Rudd, S. Liu, N. Planas, E. Bill, L. Gagliardi, C.C. Lu, Angew. Chem. Int. Ed. 52 (2013) 4449.

[15] J.P. Krogman, C.M. Thomas, Chem. Comm. 50 (2014) 5115.

[16] N.V.S. Harisomayajula, A.K. Nair, Y.-C. Tsai, Chem Commun. 50 (2014) 3391.

[17] (a) M. Carrasco, M. Faust, R. Peloso, A. Rodríguez, J. López-Serrano, E. Álvarez, C. Maya, P.P. Power, E. Carmona, Chem. Commun. 48 (2012) 3954; (b) M. Carrasco, I. Mendoza, M. Faust, R. Peloso, A. Rodríguez, J. López-Serrano, E. Álvarez, C. Maya, P.P. Power, E. Carmona, J. Am. Chem. Soc. 136 (2014) 9173; (c) M. Carrasco, I. Mendoza, E. Álvarez, A. Grirrane, C. Maya, R. Peloso, A. Rodríguez, A. Falceto, S. Álvarez, E. Carmona, Manuscript submitted to Chem. Eur. J.

[18] (a) M. Carrasco, N. Curado, E. Álvarez, C. Maya, R. Peloso, M.L. Poveda, A. Rodríguez, E. Ruiz, S. Álvarez, E. Carmona, Chem. Eur. J. 20 (2014) 6092; (b) M. Carrasco, N. Curado, C. Maya, R. Peloso, A. Rodríguez, E. Ruiz, S. Álvarez, E. Carmona, Angew. Chem. Int. Ed. 52 (2013) 3227.

[19] D. Barr, W. Clegg, R.E. Mulvey, R. Snaith, J. Chem. Soc., Chem. Commun. (1984) 469.

[20] (a) N.M. Scott, T. Schareina, O. Tok, R. Kempe, Eur. J. Inorg. Chem. (2004) 3297; (b) N.M. Scott, R. Kempe, Eur. J. Inorg. Chem. (2005) 1319; (c) W.P. Kretschmer, A. Meetsma, B. Hessen, T. Schmalz, S. Qayyum, R. Kempe, Chem. Eur. J. 12 (2006) 8969; (d) D.M. Lyubov, C. Döring, S.Y. Ketkov, R. Kempe, A.A. Trifonov, Chem. Eur. J. 17 (2011) 3824.

[21] See for example: (a) D.M. Lyubov, G.K. Fukin, A.V. Cherkasov, A.S. Shavyrin, A.A. Trifonov, L. Luconi, C. Bianchini, A. Meli, G. Giambastiani, Organometallics 28 (2009) 1227; (b) D.M. Lyubov, C. Döring, G.K. Fukin, A.V. Cherkasov, A.S. Shavyrin, R. Kempe, A.A. Trifonov, Organometallics 27 (2008) 2905.

[22] F.A. Cotton, J.G. Norman Jr., J. Coord. Chem. 1 (1971) 161. 
[23] A.B. Brignole, F.A. Cotton, Z. Dori, Z. Dori, Z. Dori, G. Wilkinson, Rhenium and Molybdenum Compounds Containing Quadruple Bonds, in Inorganic Syntheses, Vol. 13 (ed F. A. Cotton), John Wiley \& Sons, Inc., Hoboken, NJ, USA, 2007.

[24] D.J. Santure, K.W. McLaughlin, J.C. Huffman, A.P. Sattelberger, Inorg. Chem. 22 (1983) 1877.

[25] E.L. Kolychev, I.A. Portnyagin, V.V. Shuntikov, V.N. Khrustalev, M.S. Nechaev, J. Organomet. Chem. 694 (2009) 2454.

[26] M.L. Cole, A.J. Davies, C. Jones, P.C. Junk, J. Organomet. Chem. 689 (2004) 3093. 